No. 17-9

\title{
U.S. Monetary Policy and Emerging Market Credit Cycles
}

\author{
Falk Bräuning and Victoria Ivashina
}

\begin{abstract}
:
Foreign banks' lending to firms in emerging market economies (EMEs) is large and denominated primarily in U.S. dollars. This creates a direct connection between U.S. monetary policy and EME credit cycles. We estimate that over a typical U.S. monetary easing cycle, EME borrowers face a 32-percentage-point greater increase in the volume of loans issued by foreign banks than borrowers from developed markets face, with a similarly large effect upon reversal of the U.S. monetary policy stance. This result is robust across different geographical regions and industries, and holds for non-U.S. lenders, including those with little direct exposure to the U.S. economy. Local EME lenders do not offset the foreign bank capital flows; thus, U.S. monetary policy affects credit conditions for EME firms. We show that the spillover is stronger in higher-yielding and more financially open markets, and for firms with a higher reliance on foreign bank credit.
\end{abstract}

Keywords: Global business cycle, monetary policy, emerging markets, reaching for yield

JEL codes: E44, E52, F34, F44, G21

Falk Bräuning is a senior economist in the research department at the Federal Reserve Bank of Boston. His e-mail address is falk.braeuning@bos.frb.org. Victoria Ivashina is the Lovett-Learned Chaired Professor of Finance at Harvard Business School, a research associate at the National Bureau of Economic Research, and a visiting scholar at both the Federal Reserve Bank of Boston and the European Central Bank. Her e-mail address is vivashina@hbs.edu.

We are grateful for detailed feedback from José Fillat, Gita Gopinath, Şebnem Kalemli-Ozcan, Joe Peek, and Jesse Schreger. We thank participants at the World Bank-ASBA Conference "Long-Term Lending: Determinants and Effects" and the Federal Reserve Bank of Boston seminar, for helpful comments. We thank Kovid Puria for excellent research assistance.

The views expressed in this paper are those of the authors and do not necessarily represent the views of the Federal Reserve Bank of Boston or the Federal Reserve System.

This paper, which may be revised, is available on the web site of the Federal Reserve Bank of Boston at http://www.bostonfed.org/economic/wp/index.htm

This version: August 29, 2017; first version: June 2, 2017 


\section{INTRODUCTION}

For emerging market economies (EMEs), foreign bank loans are by far the most important category of cross-border capital flows, and they are denominated primarily in U.S. dollars. As of 2015, International Monetary Fund (IMF) data indicate that loans represent about half of all external liabilities of emerging market countries. By comparison, foreign bond and equity portfolio investments combined represent only about 20 percent. Much of the foreign lending comes from banks headquartered in developed economies: Bank for International Settlements (BIS) data show that roughly a third of all external liabilities of emerging markets countries are held by U.S., European, and Japanese banks. Moreover, the volume of these claims has nearly doubled since the onset of the global financial crisis, reaching about \$7 trillion in 2016. Consistent with the general dominance of the dollar in international trade (for example, Goldberg and Tille 2008, Gopinath 2016) and finance (for example, Shin 2012), we document that over 80 percent of the cross-border loans to EMEs are denominated in U.S. dollars. ${ }^{1}$ This dollarization of cross-border credit prevails over time, across different geographical regions and industries.

Given the economic significance of U.S. dollar lending by global banks to EME firms, U.S. monetary policy plays an important role as a "push factor" for the credit cycles in these economies. First, by setting the federal funds rate, U.S. monetary policy sets the short end of the dollar yield curve, thereby crucially affecting the supply of credit through banks' dollar funding cost (for example, Bernanke and Gertler 1995). Second, U.S. monetary policy influences the yields on alternative longer-term dollar investments through measures that affect the slope of the yield curve (such as unconventional monetary policy). Figure I illustrates the basic correlation between cross-border loans to EMEs and U.S. monetary policy (as measured by the U.S. federal funds rate) from 1980 through 2015. The significant correlation-tightening/easing U.S. monetary policy associated with contraction/expansion in cross-border credit—holds in levels and in changes.

\section{[FIGURE I]}

The aggregate results in Figure I, while suggestive, could also be explained by relative changes in investment opportunities around the world, or by compositional shifts in the investor base in a given country. Instead, the main results in this paper establish the connection between

\footnotetext{
${ }^{1}$ Throughout the paper, we use the BIS country classification when referring to "EMEs.”
} 
foreign bank lending in EMEs and U.S. monetary policy, using DealScan data on global loan issuance. DealScan covers primarily syndicated loans issuance, that is, loans originated and managed by a small group of banks, but funded by a wider group of creditors. However, according to Gadanecz and Von Kleist (2002), the estimated outstanding stock of syndicated loans held by foreign banks amounts to about 50 percent of all outstanding cross-border bank claims on Latin America and developing Europe, and to around 100 percent of all outstanding cross-border bank claims on Asia and the Africa-Middle East region. Overall, the data we use in this study cover loan issuance to EME borrowers from 119 countries between 1990:Q1 and 2006:Q3.

Using these detailed loan-level data, we show that U.S. monetary policy easing is associated with a general increase in cross-border loan volumes by global banks from developed countries. Moreover, there is a significant differential effect across markets: when U.S. monetary policy eases, in the same quarter, a given bank provides larger cross-border loan amounts to borrowers from EMEs than to borrowers from developed markets. This differential effect amounts to lower lending volume of about 2 percentage points per 25-basis-point increase in the U.S. federal funds rate, and it holds after controlling for borrower fixed effects. During a typical monetary easing/tightening cycle in our sample period, the Fed target rate is adjusted by about 4 percentage points. Given our estimates, this would amount to an additional increase/drop in loan volumes to emerging market borrowers of a sizable 32 percentage points. The results are robust to using country-level macroeconomic variables instead of an EME indicator and are consistent with the risk-taking channel of monetary policy (for example, Adrian and Shin 2010): a reduction in the U.S. federal funds rate pushes global bank flows more strongly into higheryielding markets (for example, measured by higher GDP growth or higher interest rates). In addition, we validate our results using BIS data that incorporate all claims held by foreign banks against EME borrowers.

Global dollar bank flows to EMEs are also driven by longer-term U.S. interest rates. In particular, we find that-holding constant the level of the yield curve set by the short-term policy rate- a reduction in the term spread (the difference between long- and short-term interest rates) is associated with a strong flow of dollar capital into EME credit markets. This effect holds throughout the sample period, but is particular relevant during the zero-lower-bound (ZLB) period when the Federal Reserve eased monetary policy through unconventional measures that 
directly impacted long-term rates. Similarly, we find that unconventional monetary easing during the ZLB period, as measured by the Wu-Xia (2016) shadow rate, strongly pushes capital into the EMEs. Consistent with the special role of U.S. monetary policy, we find that changes in Eurozone interest rates have an effect on euro-denominated credit, but do not have a significant effect on dollar-denominated credit to EME borrowers.

Monetary policy is intrinsically connected to economic fundamentals (Romer and Romer 2004). To show that the identified relationship between U.S. monetary policy and dollardenominated credit flows to EMEs is unlikely to be driven by relative or absolute changes in investment opportunities but is instead due to monetary policy, we proceed in several steps. First, we restrict our sample to dollar loans originated by non-U.S. banks to non-U.S. borrowers and show that the core result holds for lending by global banks with marginal direct exposure to the U.S. borrowers. The idea is that these banks are serving the borrowers whose investment opportunities are not directly affected by changes in U.S. economic conditions. Moreover, because we focus on loans to borrowers outside of the United States, the inclusion of quarter fixed effects in the analysis allows us to control for foreign loan demand that is correlated with U.S. economic conditions; however, it does not account for differential loan demand by EMEs. To rule out potentially different correlations between EME credit demand and U.S. economic conditions, we show that the results hold for loans to EME borrowers from (i) both non-tradable and tradable industries, (ii) sectors that produce goods and services with a low country-level export share, (iii) economies with low international trade overall, and, (iv) economies with low trade ties to the United States. We verify that the effect holds for all geographic regions.

We further show that global bank flows driven by U.S. monetary policy affect EME credit conditions at the firm level. In particular, we confirm that the contraction of credit by banks from developed market economies (DMEs) in a U.S. tightening cycle is not offset by an increase in credit by the local banks, but leads to a credit contraction and an increase in interest rate spreads for EME borrowers. During a typical U.S. monetary policy cycle where the federal funds rate is adjusted by 4 percentage points, EME borrowers would experience a 14-percentage-point stronger contraction in credit volume and a 38-basis-point stronger increase in interest rate spreads than a similar DME borrower would. To highlight the macroeconomic risks of foreign credit outflows from EMEs, we also highlight the relatively short maturity of corporate loans and the large amount of loans coming due in any given year. Related to this, we also find that U.S. 
monetary policy tightening leads to a lower probability of refinancing maturing loans for emerging market borrowers with a high reliance on foreign banks. Finally, we show that EME infrastructure financing by foreign banks is also sensitive to U.S. monetary policy; these investments are heavily dependent on international capital and, specifically, on syndicated bank credit.

At a high level, our paper contributes to the large economic literature on international spillovers via capital flows, monetary policy transmission, and the role of global financial intermediaries. Most directly, our work expands empirical evidence of a "global financial cycle" that is linked to economic conditions in the center country of the world economy (Rey 2013). In particular, using a VAR approach, Miranda-Agrippino and Rey (2015) show the importance to global asset prices of the cross-border transmission of U.S. monetary policy via financial intermediaries. In addition, McCauley, McGuire, and Sushko (2015) use aggregate data to study the effect of U.S. monetary policy on global dollar credit. Related to the special role of U.S. monetary policy, Takáts and Temesvary (2016) study the role of currency denomination in the international monetary policy transmission, using aggregate BIS data.

We provide firm-level evidence of the transmission of U.S. monetary policy through the balance sheet of global banks. Other papers that use micro data to study EME credit cycles include recent work by Baskaya et al. (2017), who look at the provision of credit in the Turkish market and connect it to changes in global risk appetite as measured by the VIX. DemirgüçKunt, Horväth, and Huizinga (2017) focus on the role of global banks' charters in foreign markets for the transmission of foreign monetary policy. Morais, Peydró, and Ruiz (2015) and Altunok et al. (2016) examine spillovers of monetary policy through global bank activities in Mexico and Turkey, respectively. In contrast with these papers, our analysis allows us to examine the question in a cross-country setting, covering more than 25 years of global loan issuance. Our emphasis is on the distinct importance of foreign bank lending and, specifically, dollar lending in the emerging markets, which is central to the transmission of U.S. monetary policy to EMEs. Bräuning and Ivashina (2017) discuss firm-level evidence on monetary policy spillovers in major developed economies, but the emphasis there is on the interaction with the currency market and part of the mechanism is specific to capital flows across major currency areas. 
Given our focus on the differential sensitivity of emerging market economies to the transmission of U.S. monetary policy, this paper expands work by Forbes and Warnock (2012), Fratzscher (2012), and Ahmed and Zlate (2014) that has highlighted the importance of U.S. economic conditions, in particular U.S. monetary policy, for capital flows into emerging markets from a bond and equity flow perspective. More broadly, our work contributes to the literature on credit cycles in emerging market economies and its implications for financial stability and economic development. For example, Acharya et al. (2015) and Shin (2016) highlight the risks to financial stability when emerging markets borrowers sharply increase dollar leverage during periods of strong capital inflows.

The remainder of the paper is organized as follows: In Section II, we present stylized facts on cross-border lending to EMEs. In Section III, we establish our main result on the effect of U.S. monetary policy on cross-border lending to EMEs. In Section IV, we discuss the consequences of foreign bank funding dependence by EMEs. Section V concludes.

\section{U.S. DOLLAR CROSS-BORDER LENDING TO EMES}

Foreign bank lending represents a significant fraction of foreign capital inflows to EMEs. As mentioned in the introduction, according to data from the IMF International Investment Position, loans represent about 50 percent of all EMEs' external liabilities. ${ }^{2}$ By comparison, Figure II (a) shows that, in 2015, portfolio (vs. direct) bond investment in EMEs represented only about 15 percent of external liabilities, and portfolio equity investment represented about less than 5 percent (these numbers refer to the median values across EMEs). Beyond the composition, bank and broader fund flows display a strong correlation: from 1990 onward, the correlation of loan flows to EMEs with equity and bond flows to EMEs is about 0.50. (This relationship is weaker in the 1980s.) This is consistent with the fact that the core results presented in this paper hold in both the DealScan dataset (which includes primarily data on large corporate loans) and the BIS dataset (which includes data on all claims held by banks.)

Global bank flows are particularly important for EMEs. Combining the IMF data with the BIS Consolidated Banking Statistics, Figure II (b) shows that about a third of all external liabilities of emerging markets are held by large global banks, twice as large a proportion as

\footnotetext{
${ }^{2}$ Data on total external liabilities are collected from the IMF statistics and include all claims of foreigners on a given country, including all equity and debt instruments.
} 
claims of global banks on developed markets. ${ }^{3}$ Moreover, the relative importance of cross-border bank claims for developed-market countries has decreased from 2005 (beginning of the detailed BIS data) to 2015, but the trend has been the opposite for emerging markets. Consistent with Giannetti and Laeven (2012), the BIS data also show that the total volume of foreign bank claims for developed market countries increased from \$12 billion in 2005 to \$25 trillion in 2008, but then declined steadily to $\$ 16$ trillion in 2016. In contrast, claims on emerging market countries increased more than threefold throughout the entire sample, from about \$2 trillion in 2005 to about $\$ 7$ trillion in 2016. A similar picture emerges from Figure III, where we plot the share of loans provided by foreign banks using the DealScan syndicated loan issuance data, the core data for our study (Table I presents sample composition by country). The figure highlights the strong and persistent reliance of EME firms on foreign bank credit. Throughout the period from 1995:Q1 through 2016:Q3, more than 80 percent of all loan commitments to EME firms were provided by foreign banks, while the share was below 50 percent for developed economies. ${ }^{4}$

\section{[FIGURES II \& III]}

The importance of global bank flows to EMEs points to the potential exposure of these markets to foreign monetary policy. Moreover, because of the dollar dominance of bank capital flows to EMEs, it is U.S. monetary policy that is likely to be most relevant, due to its strong effect on nominal U.S. interest rates. The last three columns in Table I show the country-level currency composition of cross-border credit, making it clear that the dominance of dollardenominated credit is a global phenomenon: from 1990:Q1 through 2016:Q3, the share of dollardenominated cross-border loans issued to emerging market borrowers is about 87 percent for Africa, 95 percent for the Americas, 81 percent for Asia, and 71 percent for Europe (a smaller dollar share goes hand-in-hand with a higher euro share). Table II, Panel A, shows that, for each region, the dollar dominance of cross-border credit holds broadly across borrowers from all industries (based on the 1-digit SIC code) and is not confined to the tradable sectors. ${ }^{5}$

\footnotetext{
${ }^{3}$ BIS Consolidated Banking Statistics contains cross-border claims as reported by banks from 21 developed countries. (Claims by banks from the only three emerging market countries in the sample are small.) The reported cross-border claims include all types of bank loans, but also other debt instruments and equity claims.

${ }^{4}$ Indeed, the slight decline in the share of loans to EMEs provided by foreign banks is driven entirely by an increase in domestic lending of Chinese banks.

${ }^{5}$ Note that the same currency patterns hold for syndicated loans originated by local banks; however, while syndicated credit is an important part of cross-border lending, it is likely to be a small fraction of domestic lending in EMEs.
} 
As Table II, Panel B, illustrates, dollar reliance in the broader set of assets held by foreign banks is lower than what we see for corporate loans; yet the majority of claims on emerging markets are still denominated in U.S. dollars. Other currencies, including local currencies, the British pound, or the Japanese yen, play a negligible role. The data come from BIS Locational Banking Statistics and include all claims held by foreign banks including bonds, equities, and non-corporate loans. This adds external validity to our results. For comparison, we construct the outstanding stock of loans using DealScan, by aggregating the most recent term loans in the sample that mature after 2016:Q3. Finally, in Figure IV, we highlight that dependence on dollardenominated credit is a persistent phenomenon that goes back at least two decades.

[TABLE I-II \& FIGURE IV]

The evidence presented here substantially expands the evidence presented in earlier work. For example, 69 of the EME countries covered in our sample are not covered in Gopinath (2016). Note that a large part of the samples covered by Goldberg and Tille (2008) and Gopinath (2016) are developed economies. In this study, DMEs are included in the analysis in the next section, but we discuss only the reliance on dollar-denominated credit for emerging markets due to the focus of our study. Discussion of heavy reliance on dollar credit in developed markets can be found in Ivashina, Scharfstein, and Stein (2015) and ECB (2016).

\section{U.S. MONETARY POLICY AND CROSS-BORDER LENDING}

\section{III.1 Benchmark Results}

Building on the economic significance of both cross-border bank lending and dollardenominated lending, we now focus on establishing across-market spillover of U.S. monetary policy. The dependent variable in Tables III through V is the logarithm of the total amount of cross-border dollar lending, $\log \left(L_{j i t}\right)$, by a bank $j$ to a firm $i$ in a quarter $t$. Banks are consolidated at the bank-parent level, so a loan made by a subsidiary of a U.S. bank based in Mexico to a Mexican firm is counted as a U.S. “cross-border” loan to Mexico. DealScan loan issuance data are collapsed to the quarterly format. About 2 percent of all borrowers have more than one loan from a given bank in a given quarter; in such a case we aggregate the amounts. Throughout the analysis, we consider only lenders with relatively large commitments on a given 
loan. ${ }^{6}$ The loan amount for a given bank is computed on a pro-rata basis; for example, in a \$150 million loan with three large commitments by banks, $L_{j i t}$ for each bank would be $\$ 50$ million. In our baseline analysis, our key independent variable is the effective federal funds rate, which measures the stance of U.S. monetary policy.

Table III presents our benchmark results. Panel A, column (1), shows the basic relationship between the federal funds rate and global banks' lending abroad: easing of U.S. monetary policy pushes bank flows into foreign markets, while tightening of U.S. monetary policy reduces banks' investment in foreign countries. Our hypothesis is that monetary policy has a differential effect on the bank capital flows to EMEs. Thus, in Table III, the key coefficient of interest is the one on the interaction term between the federal funds rate and a dummy variable indicating whether the borrower is domiciled in an emerging market economy. This coefficient picks up the average differential effect for capital flows to EMEs when the U.S. federal funds rate changes. Specification (2) reports the basic decomposition of the overall effect between developed and emerging markets, showing that, while directionally the results are consistent across the groups, the effect on emerging markets is roughly twice as large as the effect on developed markets. The coefficient estimates indicate that a 25-basis-point decrease in the federal funds rate increases cross-border loan volumes to firms in DMEs by about 2.25 percent, while EME firms face an increase of about 4.9 percent, a highly significant differential effect of more than 2.6 percentage points (the $t$-statistic is 6.43).

Because we know the borrower's identity and its key lenders, in specification (3) we control for bank and firm fixed effects. This helps us deal with a demand-driven explanation of changes in credit behavior by accounting for time-invariant demand factors, such as firms' size group, location, and industry. Moreover, we include quarterly time fixed effects to net out any common time variation, for example, related to global credit demand factors driven by the global business cycle or by overall changes in cross-border loan volumes over time. Hence, in this specification, we focus on the differential effect of U.S. monetary policy on cross-border loan volumes to EMEs and find that EME loan volumes react significantly more strongly to U.S. monetary policy changes than DME loan volumes do. In specification (4), we include bank-quarter fixed effects in addition to borrower fixed effects; this allows us to control for time-varying bank

\footnotetext{
${ }^{6}$ That is, we exclude lenders whose role in the syndicate is identified as merely "participant." Having a syndicate role other than "participant" qualifies a lender for league table purposes.
} 
heterogeneity, such as individual bank health or changes in business models. The identification in this case is driven by the differential loan volumes to emerging and developed countries of a given bank in the same quarter after netting out any borrower-specific, time-invariant characteristics. The result is very robust. In economic terms, the coefficient in column (4) implies that a 25-basis-point easing in the U.S. federal funds rate increases the volume of crossborder loans to borrowers from emerging markets by an additional 2 percentage points, compared with borrowers from developed markets.

In the Appendix, in Table A.I., we take a closer look at the geographic breakdown of emerging market countries and find that our baseline effect of column (4) holds across all regions. The result is only economically and statistically weaker for Latin America (the point estimate is about two-thirds of the estimated average effect). This is in line with Takáts (2010), who points out that, unlike in other EMEs, the expansion of international banks in Latin America mainly took the form of increased domestic currency lending by local affiliates, making crossborder bank lending relatively less important for these regions. Also in the Appendix, in Table A.II., we replicate our baseline result for borrowers from different industries and show that the significantly stronger effect of U.S. monetary policy on EME lending holds for both borrowers from the non-tradable and the tradable sectors, and, hence, is unlikely to be driven by correlated credit demand from EME firms in the tradable sectors.

Our baseline result in column (4) is based on using the federal funds rate as a measure of the stance of U.S. monetary policy. Indeed, the federal funds rate has been the primary tool of U.S. monetary policy for most periods in our sample. Moreover, this policy rate anchors the short end of the yield curve, thereby having a strong impact on the dollar funding cost of global banks, which is a key determinant of banks' dollar lending decisions. In column (5), in addition to the policy rate, we also include the term spread-the difference between the 10-year U.S. Treasury yield and the federal funds rate-as a direct measure of the slope of the yield curve. The coefficient estimates show that the impact of the federal funds rate (the level of the yield curve) stays qualitatively similar, but becomes quantitatively stronger. The coefficient on the term spread is negative. ${ }^{7}$ Hence, holding constant the level of the yield curve (short rate), a smaller slope of the yield curve is associated with a significant increase in EME lending volumes. This

\footnotetext{
${ }^{7}$ Historically, the term spread increases when the Fed lowers short-term rates (correlation of -0.83), as short-term rate cuts only gradually transmit to longer-term rates.
} 
finding is intuitive and is consistent with indications of reaching-for-yield motives: when alternative returns on dollar assets are low (low longer-term yields), bank capital is pushed into higher-yielding emerging market economies. Quantitatively, we estimate that a decrease of the term spread of 1 percentage point is associated with an additional increase in EME lending volumes (relative to DME lending volumes) of about 16 percentage points; such a decline in the term spread was observed from December 2008 to June 2013, when the Fed first indicated tapering of its asset purchases.

In column (6), we confirm that the connection between emerging market capital flows and U.S. monetary policy is not a recent phenomenon but holds throughout our sample, including the period before the federal funds rate was pushed to zero in 2008:Q4. Note that the coefficient estimates in this earlier part of the sample are economically smaller when compared with the estimates for the full sample. In column (7), we look at the period when the federal funds rate was at the zero lower bound (that is, the period from 2008:Q4 though 2015:Q3). During this period, the federal funds rate was not the only tool of monetary policy, as the Fed conducted additional monetary easing through unconventional policies, including forward guidance and large-scale asset purchases. In fact, during this period, the Fed committed to keeping policy rates at zero for an extended period of time. Therefore, during this period, we use the $\mathrm{Wu}$ and Xia (2016) federal funds shadow rate, which provides a single measure that takes into account unconventional monetary policy measures during the post-2008 zero-lower-bound period. We find that this additional easing in U.S. monetary policy during the zero-lower-bound period increased EME lending volumes significantly more than cross-border loan volumes to developed markets. Indeed, the coefficient estimate is roughly similar to the estimate of the federal funds rate reported in column (4).

\section{[TABLE III]}

Results in Table III, Panel A, show a strong connection between U.S. monetary policy and cross-border dollar lending to EME firms. The Fed's monetary policy actions, however, are endogenous to changes in economic conditions in the United States (Romer and Romer 2004). For example, the Fed would typically ease monetary policy when U.S. economic conditions worsen, a period when loan demand in the U.S. could be declining. This could lead to a concern that our earlier results are driven by changes in global banks' relative investment opportunities (the demand channel) and not by the effect that monetary policy has on cross-border dollar 
credit. We start to address this concern by restricting our sample to loans originated by non-U.S. banks to non-U.S. borrowers. Importantly, we consider only loans by non-U.S. banks with a low exposure to the U.S. economy. The idea is that banks with low exposure to the U.S. economy are serving the borrowers whose investment opportunities are not directly affected by changes in U.S. economic conditions.

We measure a bank's exposure to the U.S. economy by the share of cross-border loans to U.S. borrowers relative to all cross-border loans over our sample period. Results are robust to measuring banks' U.S. exposure based on a rolling window instead. About 25 percent of banks in our sample have no lending to U.S. borrowers; but, these banks account for only 1 percent of all loans. Instead, we define low-U.S.-exposure banks as banks with less than 5 percent (and, as a robustness check, 10 percent) of loans to U.S. borrowers. These low-U.S.-exposure banks account for roughly 10 percent of all loans (25 percent for the 10-percent-exposure cutoff). The results, reported in Table III, Panel B are comparable to those shown in Panel A, column (5). The first two columns of Panel B show that, for non-U.S. banks with low direct exposure to the U.S. economy, the significantly stronger increase of EME loan volumes continues to hold. In column (2) - loans by non-U.S. banks with less than 5 percent of their loans to U.S. borrowers, - we find a significant, albeit quantitatively and statistically weaker (t-statistic of 1.79), differential effect for EMEs.

A drop in economic activity in the United States (correlated with an easing monetary policy) is likely to negatively affect U.S. suppliers and EME exporters more broadly. This suggests a positive correlation between U.S. economic conditions and EME loan demand, which should bias our estimates downward. In columns (3) to (6), we therefore look at loans originated by nonU.S. banks with a low U.S. exposure to EME firms that are unlikely to be affected by changes in investment opportunities in the U.S. economy. Specifically, in column (3), we look at loans to EME firms from the non-tradable sectors based on the 1-digit SIC classification as reported in DealScan. In column (4), we identify, for each EME country separately, borrowers that produce goods and services that have a low export share relative to all exports of each country (goods and services with an export share smaller than the $25^{\text {th }}$ percentile of the within-country distribution). In column (5), we look at loans to EME firms from countries with low trade (trade relative to the country's GDP smaller than the $25^{\text {th }}$ percentile of the cross-country distribution), and in column (6) we look at loans to EME firms from countries with low trade with the United States (U.S. 
trade relative to the country's total trade smaller than the $25^{\text {th }}$ percentile of the cross-country distribution). Country-level data on trade statistics are presented in Table I. The results show that once we focus loans by non-U.S. banks with low U.S. exposure to borrowers that are unlikely to have a strong link to U.S. economic conditions (and hence their time-varying loan demand is orthogonal to U.S. economic conditions), we see that the differential effect of U.S. monetary policy on EME loan volumes indeed becomes larger and statistically more significant. For example, when we focus on loans to EME firms from countries that have weak trade linkages with the United States, the coefficients on the federal funds rate are over twice the size of the estimates based on the full sample loans (column 6 in Panel A). Economically, these borrowers experience a sizable 8.7-percentage-point stronger loan volume increase when the federal funds rate decreases by 25 basis points compared with a similar DME firm.

So far, we used a coarse measure to identify EME borrowers, based on the BIS classification. In Table IV, we look instead at the underlying country characteristics (compiled from World Bank information) and examine how these characteristics interact with U.S. monetary policy. In column (1), we find that borrowers from countries with higher GDP growth receive larger loan volumes. This result controls for borrower fixed effects; the coefficient is therefore identified from variation in the interest rate spread of a given country. The level effect indicates that a 1percentage-point increase in the borrower country's GDP growth is associated with a 1.4 percent increase in cross-border loan volumes. Moreover, as the negative coefficient on the interaction term indicates, borrowers in these countries are also more sensitive to capital in/out-flows when U.S. monetary policy eases/tightens. Similarly, high-GDP-growth countries are more sensitive to global bank flows when the U.S. term spread changes (column 2). The estimate on the interaction term indicates that sensitivity to the U.S. federal funds rate increases by about 0.6 percentage points when the borrower country's GDP growth increases by 1 percentage point. In columns (3) and (4), we show that the stronger sensitivity of bank flows to U.S. monetary policy holds when we use another measure for a high-yield market - the difference between the borrower country's interest rate and the U.S. federal funds rate. The estimate on the interaction term indicates that the sensitivity to U.S. monetary policy changes increases by about 0.3 percentage points when the interest spread increases by 1 percentage point. Qualitatively similar results hold when we consider higher growth in their national stock market index as a proxy for high-yield markets. (The underlying sample changes, due to data availability.) In column (7), we 
find that borrowers from high-risk countries (as measured by the lagged rating for long-term sovereign debt collected from Fitch Ratings) receive smaller loan amounts. However, the negative coefficient on the interaction term shows that loan volumes to high-risk countries increase more strongly than loan volumes to low-risk countries if U.S. interest rates decrease, in terms of both a lower federal funds rate and a lower term spread (column 8). Overall, the evidence is in line with reaching-for-yield behavior, where DME banks increase syndicated loan originations in riskier and high-growth markets when U.S. interest rates are low (for example, Bruno and Shin 2015).

\section{[TABLE IV]}

\section{III.3 Specialness of U.S. Monetary Policy}

U.S. monetary policy affects banks' overnight dollar funding cost and can influence the yield on alternative longer-term dollar investments. Given that cross-border lending to EMEs is denominated primarily in dollars, we postulated that U.S. monetary policy plays a special role in driving global dollar credit flows to EMEs. In Table V, we provide further evidence on the specialness of U.S. monetary policy by looking at monetary policy in the euro area.

Historically, there has been strong co-movement between monetary policy decisions taken by the Fed and those taken by the European Central Bank (ECB). Between 1999 (the introduction of the euro) and 2016, the correlation between the euro overnight interest rate (EONIA) and the federal funds rate is 0.81 and the correlation of the 10 -year term spreads is 0.60 . It is therefore not surprising that if we just replace the U.S. variables with their equivalents for the euro area, the results will be economically and statistically similar, see column (1) of Table V. Instead, in specification (2), we expand our baseline specification (Table III.A, column (5)) to include both the U.S. and the European interest rate and term spread. We find that the estimates of the eurorelated variables are close to zero and are statistically insignificant, while the coefficients on the dollar variables remain economically large and statistically significant. In specification (3), we exclude U.S. lenders from the sample and show that non-U.S. banks also adjust their dollar lending to EMEs in response to changes in U.S. monetary policy. The estimates are economically very similar to those with the full sample. In column (4), we show that the results also hold for quarters with the opposite movement in monetary policy stance; for example, 
quarters when the United States was in a tightening cycle and the euro area in an easing cycle. ${ }^{8}$ From 1999:Q1 through 2016:Q3, there are 20 such quarters, where the stance of U.S. and euroarea monetary policy differed. Finally, in column (5), we look at the euro-denominated crossborder lending of U.S. banks to non-euro borrowers and confirm that for this currency the euro interest rate does matter.

\section{[TABLE V]}

\section{III.3 Macro-Level Evidence}

By looking at the syndicated loan data, we can (i) focus on corporate loans, (ii) analyze new loan issuance (vs. stock), (iii) focus on specific currencies, (iv) look at the sample dating back to 1990, and (v), most importantly, identify individual borrowers and lenders to address alternative explanations for our findings. While this cannot be done with aggregate BIS data, it is informative to examine whether a similar relationship between U.S. monetary policy and bank capital flows from developed to emerging markets holds in this sample, especially given that the BIS data are not constrained to syndicated credit but include all forms of claims held by the banks. In Table VI, we look at the logarithm of the cross-border claims, $\log \left(C_{J I t}\right)$, by a banking sector in country $J$ on nonbank private firms in country $I$ (for example, all claims held by British banks on nonbank firms in Kenya) in quarter $t$. The data are from BIS Consolidated Banking Statistics and cover the period from 2005:Q1 to 2016:Q3.

Table VI, column (1), shows that overall cross-border claims on nonbank firms increase when there is monetary policy easing in the United States. Similar to the results in Table III, when we look more closely to see in which countries banks invest when there is U.S. monetary policy easing, we see that the effect is largely driven by investments in emerging markets (column 2). In column (3), we add time fixed effects, banking-sector country fixed effects, and borrower-country fixed effects, thereby mimicking our set of fixed effects from Table III. The significance of the differential effect in the sensitivity to U.S. monetary policy between claims to emerging and developed market countries is robust to the inclusion of these controls. In economic terms, specification (3) shows that emerging market claims increase by an additional 2.5 percentage points compared with developed market claims when the U.S. eases monetary policy by 25 basis points. In column (4), we add banking-sector-quarter fixed effects to the

\footnotetext{
${ }^{8}$ We define a tightening/easing cycle based on quarters when the policy rate increased/decreased and all subsequent quarters where the rate was not decreasing/increasing until a reversal of policy occurred.
} 
specification, which allows us to control for any time-varying heterogeneity at the bankingsector level. For example, this would accommodate a general contraction in credit abroad of all Japanese banks due to problems in the Japanese banking sector like the shock examined by Peek and Rosengren (1997, 2000). Inclusion of these tighter controls slightly decreases the size of the estimates, but the relationship between monetary policy and bank activity in the emerging markets remains strong. Inclusion of the term spread renders similar results to those of the loanlevel analysis (column 5).

\section{[TABLE VI]}

In columns (6) and (7), we look at cross-border interbank claims from banks in developed markets on banks in EMEs. In some countries (for example, Turkey) global banks' capital flows are intermediated by the domestic banking sector. In such settings, the negative impact of capital outflows might be amplified due to increased leverage of the domestic banking sector. From results in Table VI, we see that interbank claims on banks in emerging markets (relative to crossborder claims on banks from developed markets) increase strongly when U.S. monetary policy eases. Indeed, the point estimates suggest that the effects are more than twice as large as the estimates for claims on nonbank firms. We also verify that this result holds across different EME regions (unreported). However, BIS data indicate that cross-border interbank claims are smaller, with claims on EME banks being about a third of the value of claims on EME (non-bank) firms on average.

Rajan (2014) points out that "[c]ountries that undertake textbook policies of financial sector liberalization are not immune to the inflows-indeed, their deeper markets may draw more flows in, and these liquid markets may be where selling takes place when conditions in advanced economies turn.” We examine this proposition in Table VII using the financial openness index of Chinn and Ito (2006), which measures the degree of a country's capital account openness based on various restrictions on cross-border financial transactions. The index ranges from 0 (no financial openness) to 1 (full financial openness) and is available at a quarterly frequency through the end of 2014. Unfortunately, there is limited time variation of this measure for a given country. Given that the analysis is effectively cross-country, we report results using the BIS dataset, which has broader coverage of EME countries at the quarterly frequency than DealScan.

Column (1) of Table VII shows that—as one would expect—foreign banks hold more claims on private nonbank entities from EME countries that are more financially open. Note that the 
regression includes banking-sector country and host-country fixed effects; therefore, the coefficient is identified from changes in financial openness of a given country over time. In column (2), we test whether bank capital flows to financially open countries are more sensitive to U.S. monetary policy. Indeed, the negative estimate indicates that financially open countries have a larger increase in bank claims when U.S. monetary policy eases and a stronger retrenchment when monetary policy tightens. The coefficient estimate in column (3) is robust to a tight set of fixed effects and indicates that if the financial openness index of a given country increases by one standard deviation (0.34), the sensitivity of cross-border claims to U.S. monetary policy increases by an additional 2.4 percentage points $(-0.07 * 0.34)$. We do not find a significant interaction with the term spread in column 4. The result is quantitatively robust to controlling for country risk in column (5), and, therefore, is not driven by the possibility that changes in a country's financial openness may be correlated with a different (time-varying) risk profile. (The change in sample from column 4 to 5 is due to limited data availability of country ratings.)

\section{[TABLE VII]}

\section{CONSEQUENCES OF FOREIGN CREDIT DEPENDENCE}

Results presented so far indicate a substantial dependence of foreign-dollar credit to EME borrowers on the stance of U.S monetary policy. We next analyze the extent to which the large capital inflows during periods of U.S. monetary easing and the subsequent retrenchment of foreign capital during a U.S. monetary policy contraction affect the credit conditions of EME borrowers at the firm level. After all, at the individual-firm level, inflows and outflows of foreign capital may just lead to a substitution between foreign and domestic lenders, leaving overall firm-level funding conditions unchanged. Thus, studying substitution effects at the individual-

firm level is crucial to assess the dependence of local credit cycles in emerging markets on the stance of U.S. monetary policy. While Table VIII presents the detailed analysis, Figure V shows that such substitution is unlikely, given a slightly positive correlation between cross-border and local lending in EMEs.

In Table VIII, the dependent variable is the logarithm of the total amount of dollar lending to a firm in a given quarter (that is, $\log \left(L_{i t}\right)$ ) by (a) all foreign banks (columns 1 and 2), (b) all domestic banks (column 3), and (c) all banks (columns 4 through 6). 
In columns (1) through (4), we focus on firms with both foreign and local creditors in a given quarter. In columns (1) and (2), the estimates show that the change in the cross-border credit volume in response to U.S. monetary policy is stronger for firms from emerging markets than for firms with developed markets. The coefficient estimate in column (2) indicates that in response to a decline in the U.S. federal funds rate of 25 basis points, cross-border lending volumes to EME firms increase by 1.9 percentage points more than the respective cross-border volumes to comparable DME firms. (This amounts to an average reduction of $\$ 7.25$ million.) On the other hand, if U.S. monetary policy tightens, local banks do not offset the contraction in foreign bank credit by increasing their lending volumes to local EME firms (column 3). Indeed, the estimate indicates that not only foreign, but also local dollar credit contracts. We estimate that local lenders reduce their lending by 2 percentage points, or $\$ 4.8$ million, per 25-basis-point increase in the federal funds rate. Overall, due to the strong reduction of foreign bank credit and the lack of substitution between local and foreign lenders, U.S. monetary policy tightening of 25 basis points leads to a 2-percentage-point stronger overall decline in dollar credit for emerging market firms (column 4) than for developed market firms. While the lack of substitution might not be surprising in the banking context, this result is in sharp contrast to findings that for securities markets local investors (at least partly) offset a decline in foreign holdings (see Forbes and Warnock 2012). The lack of substitution, in turn, magnifies the overall effect that foreign capital withdrawal might have on the economy (Caballero and Simsek 2017).

In columns (5) through (8), we broaden our sample and consider any firm that obtained cross-border funding in a given quarter, that is, firms that are exposed to global bank capital flows. In columns (5) and (6), we also see that in the broader sample EME firms face significantly stronger loan volume changes in response to U.S. monetary policy than DME firms face. In column (6), the estimated coefficient indicates a reduction of about 1 percentage point per 25-basis-point increase in the federal funds rate. Column (6) also shows the coefficient on the U.S. term spread, which is directionally consistent with our earlier findings but not significant at a conventional level. In columns (7) and (8), we estimate the effect of U.S. monetary policy changes on the interest rate spread paid by firms on their dollar borrowing, which we compute as the average all-in-drawn spread to the 3M LIBOR rate based on all loans taken out by the borrower in a given quarter. (The sample changes from column (6) to (7) because the interest rate data are not available for all loans.) The positive point estimate indicates not only that EME 
firms face higher sensitivity of volumes than DME firms, but also that the price of credit is more sensitive for EME firms than for DME firms to changes in U.S. interest rates. This holds for both the federal funds rate and the term spread. For example, in column (8), we estimate that a 25basis-point increase in the federal funds rate increases the interest rate spread by 2.4 basis points more for EME firms than for comparable DME firms. We estimate a quantitatively similar effect for an increase in the term spread.

\section{[FIGURE V \& TABLE VIII]}

Intuitively, EME firms that are more dependent on foreign bank credit may be more affected than other EME firms by fluctuations in cross-border capital flows triggered by U.S. monetary policy changes. To test this intuition, we restrict our sample to EME firms and compute for each firm its dependence on foreign bank credit. More precisely, for each firm-quarter, we compute the number of foreign banks that lent to the firm (relative to the total number of banks that lent to that firm) in the last quarter when the firm was obtaining a loan. The explanatory variable of interest is the interaction term between this foreign bank-reliance measure and the U.S. federal funds rate. The results are reported in Table IX.

In columns (1) through (4), we focus on the logarithm of the total volume of dollar borrowing by an EME firm in a given quarter. Column (1) shows that-consistent with our previous results - the U.S. interest rate is negatively associated with the borrowing amounts. Moreover, the positive coefficient on the foreign bank-reliance variable indicates that banks with more reliance on foreign banks borrow larger amounts. Our focus is on the interaction term between the U.S. interest rate and the foreign bank-reliance variable. In column (3), once we control for borrower and quarter fixed effects, thus focusing on the cross-section of borrowers, we find a negative coefficient estimate, indicating that firms with a higher reliance on foreignbank credit experience a larger decline in lending volumes when U.S. monetary policy tightens than similar firms with a lower reliance on foreign banks. For example, if U.S. interest rates increase by 25 basis points, we estimate that a firm with a one-standard-deviation larger foreign bank reliance share (0.32) experiences an additional reduction in total borrowing of about 28 basis points. This effect becomes somewhat larger once we also include the interaction with the term spread, but the estimate loses significance ( $t$-statistic of -1.19).

In columns (5) and (6), we analyze the interest rate spreads of EME firms, depending on their past foreign bank reliance. In column (6), the point estimates indicate that in general EME firms 
with higher foreign bank reliance pay smaller interest rate spreads (a one-standard-deviation larger foreign bank share reliance is associated with a 25-basis-point lower spread). However, they also experience a larger sensitivity of spreads with respect to both changes in the federal funds rate and the U.S. term spread. For example, if the federal funds rate increases by 25 basis points, we estimate that a firm with a one-standard-deviation larger foreign bank reliance would face a 1.2-basis-point larger increase in spreads $(14.43 * 0.32 * 0.25)$, while a similar increase in the term spread would lead to a 1.9-basis-point larger increase in spreads $(25.392 * 0.32 * 0.25)$.

Concerns may arise that the results on credit volumes and spreads take into account only granted loans (intensive margin of credit) and do not capture the extensive margin of credit (new loan issuance). To understand the importance of this point, we should emphasize the relatively short maturity of corporate loans: the median maturity of a corporate loan in our sample is five years (mean of 4.3 years). As of the end of 2016, roughly half of the loans outstanding matured within two years, which points to a substantial macroeconomic risk. To address this issue, in Table IX, columns (7) and (8), we estimate the probability of refinancing maturing loans to EME firms. More precisely, for each firm, we look at those quarters where an existing dollar loan matures. We then construct a dummy variable that equals one when we also observe a new loan to the firm, and zero otherwise. As before, we focus on the variation related to the U.S. monetary policy pass-through by foreign banks, holding constant firm and time characteristics.

In column (7), Table IX, we find that if U.S. monetary policy tightens, EME firms with higher foreign bank reliance face a significantly lower probability of refinancing their maturing loans. A 25-basis-point increase in U.S. interest rates lowers the probability of refinancing by about 2 basis points for each standard deviation (0.32) increase in foreign bank reliance ($0.023 * 0.25 * 0.32$ ). This corresponds to a 1 percent reduction when compared with the average probability of refinancing of 16.3 percent in our sample. In column (8), the effects become more than twice as large, once we also include the interaction term between the past foreign bank reliance and the U.S. term. Moreover, we also find that changes in the term spread transmit differentially to EME firms' probability of refinancing, depending on their past foreign bank reliance.

\section{[TABLE IX]}

As a final reflection in this paper, we look at the financing of large infrastructure projects, that is, projects related to the provision of essential services that are relevant for the broader 
economic development and growth of an economy. The idea is to look at lending to a segment that has an unambiguous impact on the real economy. It is also a segment that is likely to be very sensitive to the availability of foreign bank financing (for example, Ehlers 2014, World Bank 2016). Indeed, the alternative to privately syndicated credit is loans from multinational institutions, which tend to follow a very different and intense compliance process. ${ }^{9}$ It is also broadly acknowledged that global infrastructure needs largely exceed infrastructure investments, a gap that is anticipated to increase in the future. ${ }^{10}$ So, whereas some skepticism might remain as to how hard it is to find alternative financing for corporate investing or whether this type of credit is beneficial in first place, infrastructure investment is high-impact investment for which it is very difficult to find a substitute for global banks' funding. Infrastructure lending is an important part of our sample: DME banks have increased investment in infrastructure projects in EMEs during the last 25 years, rising to a total volume of $\$ 25.8$ billion in 2014, which equals 13.5 percent of all new loan volumes committed to EME borrowers. In the Appendix, we show that easing of U.S. monetary policy increases loan origination of infrastructure projects in EMEs to a significantly greater degree than in developed markets.

\section{CONCLUSIONS}

The mandates of central banks are typically focused on domestic economic conditions and do not account for potential international spillovers. There are some isolated examples of collaboration among monetary authorities of major currency areas, but EMEs remain outside of these coordination efforts. Following the 2008 financial crisis, this issue has resurfaced in the public debate in the context of large capital inflows into EMEs associated with unprecedented monetary policy accommodation in major currency areas, through both conventional and unconventional measures. Rajan (2014) postulates that emerging market countries wish for stable global capital inflows instead of flows pushed in by foreign monetary policy and points to the unlikelihood that local policy measures will be effective to counteract the global forces. But substantial skepticism about whether a global macro-prudential approach to monetary policy is

\footnotetext{
${ }^{9}$ As an example, failure to close a private syndication due to the unravelling of the 2008 financial crisis led to a roughly two-year delay in raising debt funding from multinationals for a construction project of the Egyptian Refinery Corporation.

10 For example, http://www.mckinsey.com/industries/capital-projects-and-infrastructure/our-insights/bridgingglobal-infrastructure-gaps
} 
necessary still remains among economists and monetary authorities (for example, Bernanke 2013).

In this paper, we provide evidence on the dominance of dollar-denominated credit in crossborder lending. Outstanding shares of foreign banks' dollar credit for African, American, and Asian emerging economies are over 90 percent. Even for emerging Europe this number is 60 percent. This point highlights the special role that U.S. monetary policy plays in the formation of credit cycles in EMEs (and the limited role of the local monetary policy). We also show that the availability of foreign bank credit to EME firms - by far the largest category of foreign capital channeled through financial intermediaries into EMEs-is strongly connected to U.S. monetary policy. This effect disproportionately affects EME borrowers as compared with borrowers in developed markets. We estimate that, during a typical monetary easing cycle over which the Fed cuts its target rate by about 4 percentage points, the increase in loan volumes to emerging market borrowers exceeded the flow into developed markets by 32 percent. On the flip side, a monetary policy tightening would pull out bank flows from emerging markets and lead to a strong contraction of foreign credit in emerging markets. The granularity of the data allows us to control for borrower time-invariant characteristics as well as for bank-quarter level effects in lending. We show that the effect holds for non-U.S. banks, for banks with very small exposure to the United States in their portfolio, for EME borrowers in the non-tradable industries, for borrowers in countries with limited trade linkages to the United States and overall—and, only for U.S.denominated credit. 


\section{References}

Acharya, Viral, Stephen G. Cecchetti, José De Gregorio, Şebnem Kalemli-Özcan, Philip R. Lane, and Ugo Panizza. 2015. "Corporate Debt in Emerging Economies: A Threat to Financial Stability?” The Brookings Institution and the Centre for International Governance Innovation.

Adrian, Tobias, and Shin, Hyun Song. 2010. "Financial Intermediaries and Monetary Economics," in: Benjamin M. Friedman \& Michael Woodford (ed.), Handbook of Monetary Economics, edition 1, volume 3, chapter 12, pages 601-650. Elsevier.

Ahmed, Shaghil, and Andrei Zlate. 2014. "Capital Flows to Emerging Market Economies: A Brave New World?" Journal of International Money and Finance 48(PB): 221-248.

Altunok, Fatih, Inci Gumus, Tümer Kapan, and Steven Ongena. 2016. “The Effect of US Unconventional Monetary Policies on Bank Lending in Emerging Markets: Evidence from Turkey.” Working paper.

Baskaya Yusuf S., Julian di Giovanni, Şebnem Kalemli-Ozcan, and Mehmet F. Ulu. 2017. "International Spillovers and Local Credit Cycles.” Working paper.

Bernanke, Ben. 2013. "Monetary Policy and the Global Economy.” Speech at the Suntory and Toyota International Center for Economics and Related Disciplines, London, 2013, March 25.

Bernanke, Ben, and Mark Gertler. 1995. “Inside the Black Box: The Credit Channel of Monetary Policy Transmission,” Journal of Economic Perspectives 9(4): 27-48.

Bräuning, Falk, and Victoria Ivashina. 2017. “Monetary Policy and Global Banking.” NBER Working Paper No 23316.

Bruno, Valentina, and Hyun Song Shin. 2015. "Capital Flows and the Risk-Taking Channel of Monetary Policy.” Journal of Monetary Economics 71(C): 119-132.

Caballero, Ricardo J., and Alp Simsek. 2017. “A Model of Fickle Capital Flows and Retrenchment”, Working Paper.

Chinn, Menzie D., and Hiro Ito. 2006. "What Matters for Financial Development? Capital Controls, Institutions, and Interactions.” Journal of Development Economics 81(1): 163192.

Demirgüç-Kunt, Asli, Balint Horväth, and Harry Huizinga. 2017. "Foreign Banks and International Transmission of Monetary Policy.” World Bank Policy Research Working Paper 7937.

Ehlers, Torsten. 2014. “Understanding the Challenges for Infrastructure Finance,” BIS Working Paper No. 454.

European Central Bank (ECB). 2016. “The International Role of the Euro.” European Central Bank Report, June 2016. 
Forbes, Kristin J., and Francis E. Warnock. 2012. "Capital Flow Waves: Surges, Stops, Flight, and Retrenchment.” Journal of International Economics 88(2): 235-251.

Fratzscher, Marcel. 2012. "Capital Flows: Push versus Pull Factors and the Global Financial Crisis.” Journal of International Economics 88(2): 341-356.

Gadanecz, Blaise, and Karsten Von Kleist. 2002. "Do Syndicated Credits Anticipate BIS Consolidated Banking Data?” BIS Quarterly Review March, 2002: 65-74.

Giannetti, Mariassunta, and Luc Laeven. 2012. “The Flight Home Effect: Evidence from the Syndicated Loan Market during Financial Crises.” Journal of Financial Economics 104(1): 23-43.

Goldberg, Linda, and Cédric Tille. 2008. “Vehicle Currency Use in International Trade.” Journal of International Economics 76: 177-192.

Gopinath, Gita. 2016. “The International Price System.” Jackson Hole Symposium Proceedings, 2016.

Ivashina, Victoria, David Scharfstein, and Jeremy Stein. 2015. "Dollar Funding and the Lending Behavior of Global Banks.” Quarterly Journal of Economics 1241-1281.

McCauley, Robert N., Patrick McGuire, and Vladyslav Sushko. 2015. "Global Dollar Credit: Links to US Monetary Policy and Leverage.” BIS Working Paper No. 483.

Miranda-Agrippino, Silvia, and Hélène Rey. 2015. "World Asset Markets and the Global Financial Cycle.” NBER Working Papers 21722.

Morais, Bernardo, Jose-Luis Peydró, and Claudia Ruiz. 2015. “The International Bank Lending Channel of Monetary Policy Rates and QE: Credit Supply, Reach-for-Yield, and Real Effects.” International Finance Discussion Papers 1137.

Peek, Joe, and Eric Rosengren. 1997. “The International Transmission of Financial Shocks: The Case of Japan.” American Economic Review 87(4): 495-505.

Peek, Joe, and Eric Rosengren. 2000. "Collateral Damage: Effects of the Japanese Bank Crisis on Real Activity in the United States.” American Economic Review 90(1): 30-45.

Rajan, Raghuram. 2014. “Competitive Monetary Easing: Is It Yesterday Once More?” Speech at the Brookings Institution, Washington DC, 2014, April 10.

Rey, Hélène. 2013. "Dilemma Not Trilemma: the Global Cycle and Monetary Policy Independence.” Jackson Hole Symposium Proceedings, Federal Reserve Bank of Kansas City, pages 1-2.

Romer, Christina D., and Romer, David H. 2004. “A New Measure of Monetary Shocks: Derivation and Implications.” American Economic Review 94 (4): 1055-1084.

Shin, Hyun-Song. 2016. “Global Liquidity and Procyclicality.” Presentation at the World Bank Conference, "The State of Economics, the State of the World," Washington DC, 2016, June 8. 
Shin, Hyun-Song. 2012. “Global Banking Glut and Loan Risk Premium.” IMF Economic Review 60(2): 155-192.

Takáts, Elöd. 2010. “Cross-Border Bank Lending to Emerging Market Economies.” BIS Working Papers No. 54.

Takáts, Elöd, and Judit Temesvary. 2016. "The Currency Dimension of the Bank Lending Channel in International Monetary Transmission.” BIS Working Papers No. 600.

World Bank. 2016. “PPI Investments in IDA Countries, 2011 to 2015.”

Wu, Jing, and Fan Xia. 2016. "Measuring the Macroeconomic Impact of Monetary Policy at the Zero Lower Bound." Journal of Money, Credit and Banking, 48(2-3): 253-291. 


\section{FIGURE I}

CROSS-BORDER LOANS TO EMERGING MARKETS AND U.S. MONETARY POLICY: 1980-2015

(a) Relationship in Levels

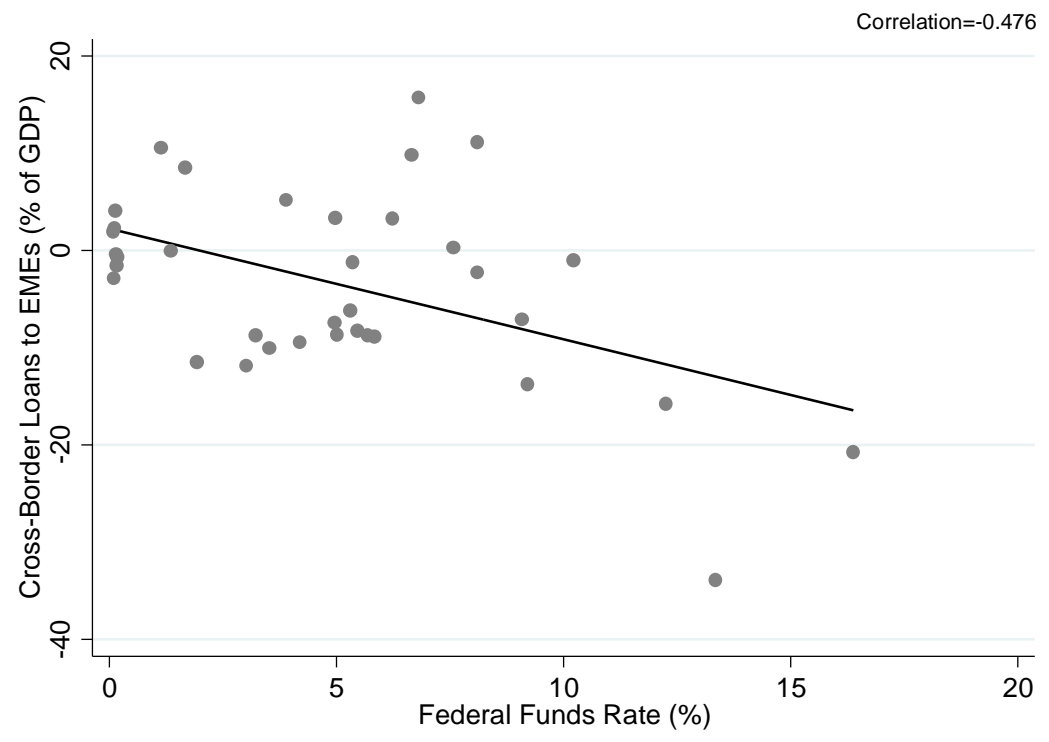

(b) Relationship in Changes

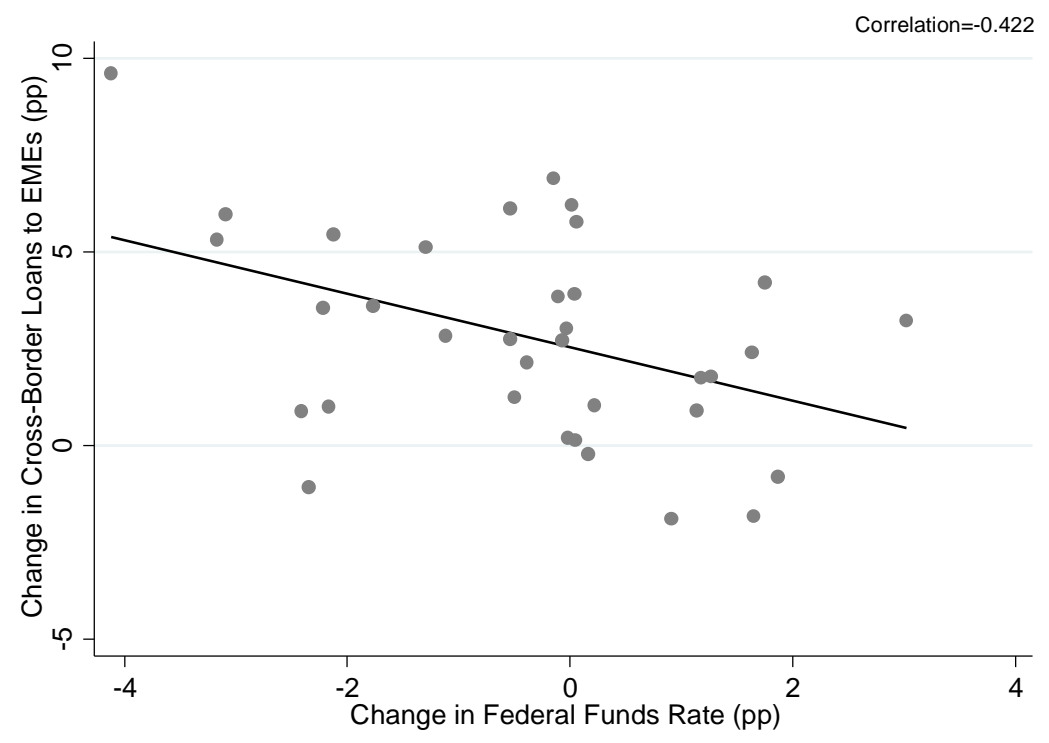

Note: This figure shows the relationship between cross-border loans to emerging market economies (EMEs) and U.S. monetary policy. Panel (a) plots the annual cross-border loans (as a percentage of GDP) against the annual U.S. federal funds rate. Panel (b) plots the annual change in cross-border loans (normalized with lagged GDP) against the annual change in the U.S. federal funds rate (in percentage points). Data on cross-border loans are compiled from the IMF International Investment Positions and cover the period from 1980 to 2015. Each observation in the plots corresponds to the median across 43 EMEs.

Source: Authors' calculations based on IMF data. 


\section{FIGURE II}

\section{CROSS-BORDER ClAims ON EMERGING AND DEVELOPED MARKET COUNTRIES}

(a) Breakdown by Instrument

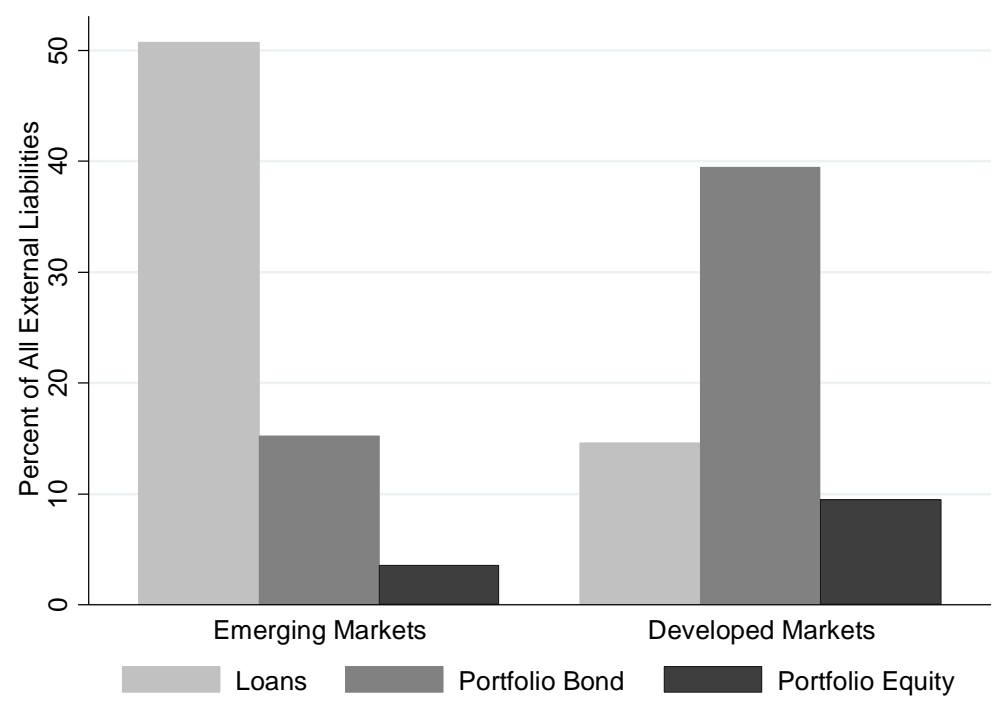

(b) Importance of Foreign Banks

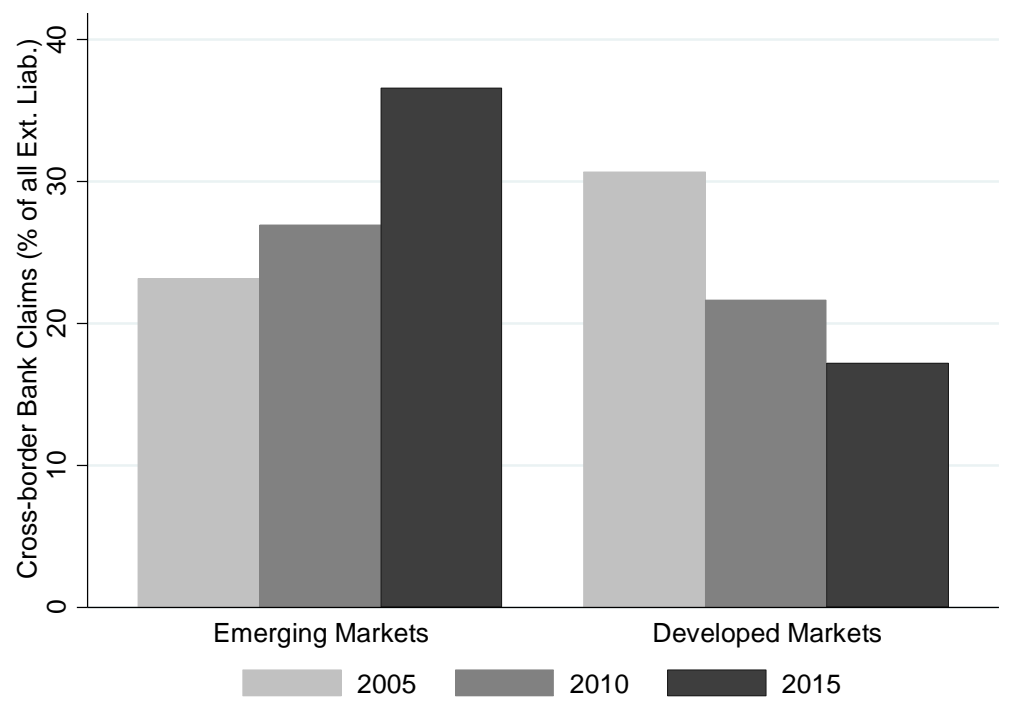

Note: This figure shows the composition of cross-border claims on countries in emerging markets (EMEs) and developed markets (DMEs). Panel (a) shows the amount of loans, portfolio bond, and portfolio equity investment held by foreigners relative to the total amount of all external liabilities in 2015. Panel (b) shows the share of external liabilities held by foreign banks. Both figures show the median values within each country group. Data on external liabilities are compiled from the IMF International Investment Position. Data on cross-border bank claims are compiled from the BIS Consolidated Banking Statistics, which has cross-border claims held by 24 banking sectors. The sample in both figures contains the same set of 29 DMEs and 43 EMEs. Source: Authors' calculations based on IMF and BIS data. 
FIGURE III

RELIANCE ON FOREIGN BANKS

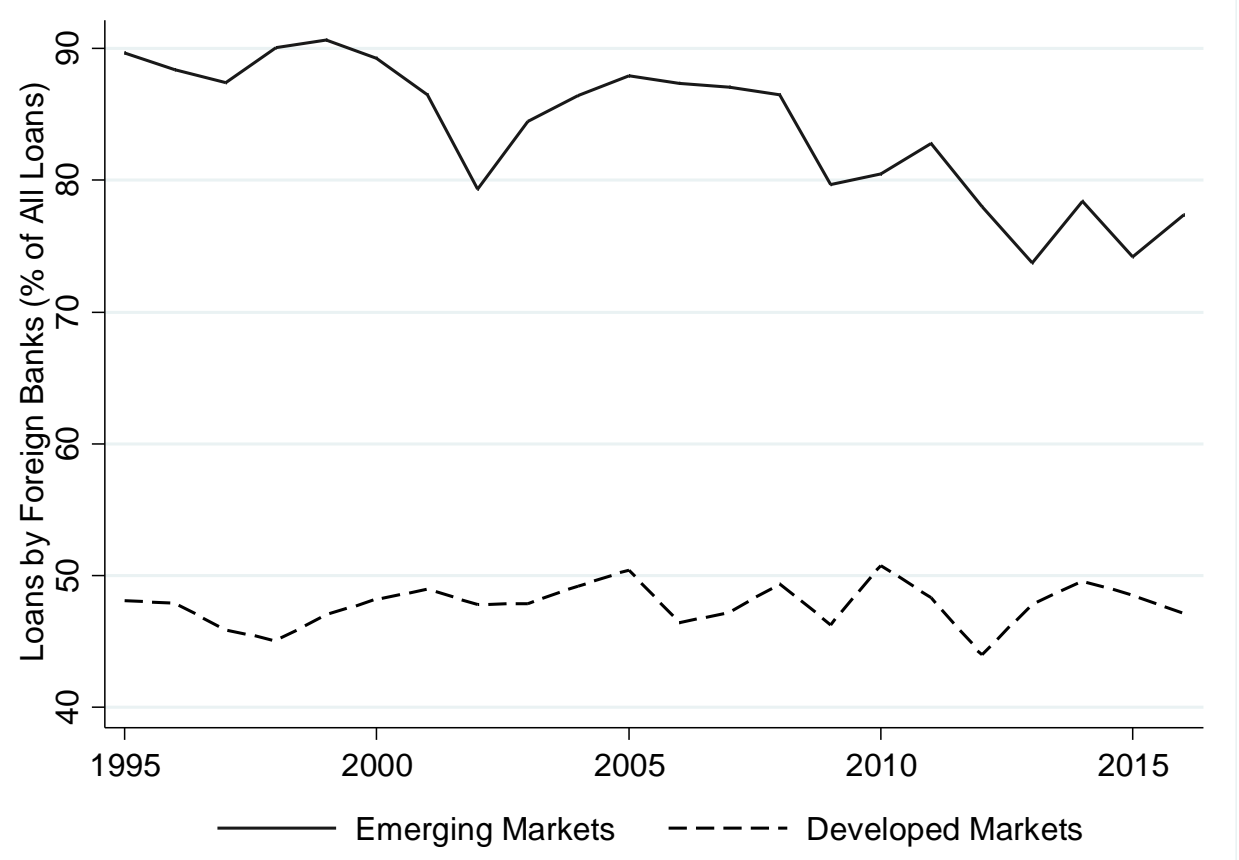

Note: This figure shows the quarterly share of loan commitments by foreign banks (relative to all loans) to borrowers in developed and emerging markets. The sample covers the period from 1995:Q1 through 2016:Q3 and includes the full DealScan dataset, with borrowers from 119 EMEs and 32 DMEs.

Source: Authors' calculations based on DealScan data. 
FIGURE IV

CURRENCY BREAKDOWN OF CROSS-BORDER LOANS TO EMERGING MARKET ECONOMIES

(a) Emerging Africa

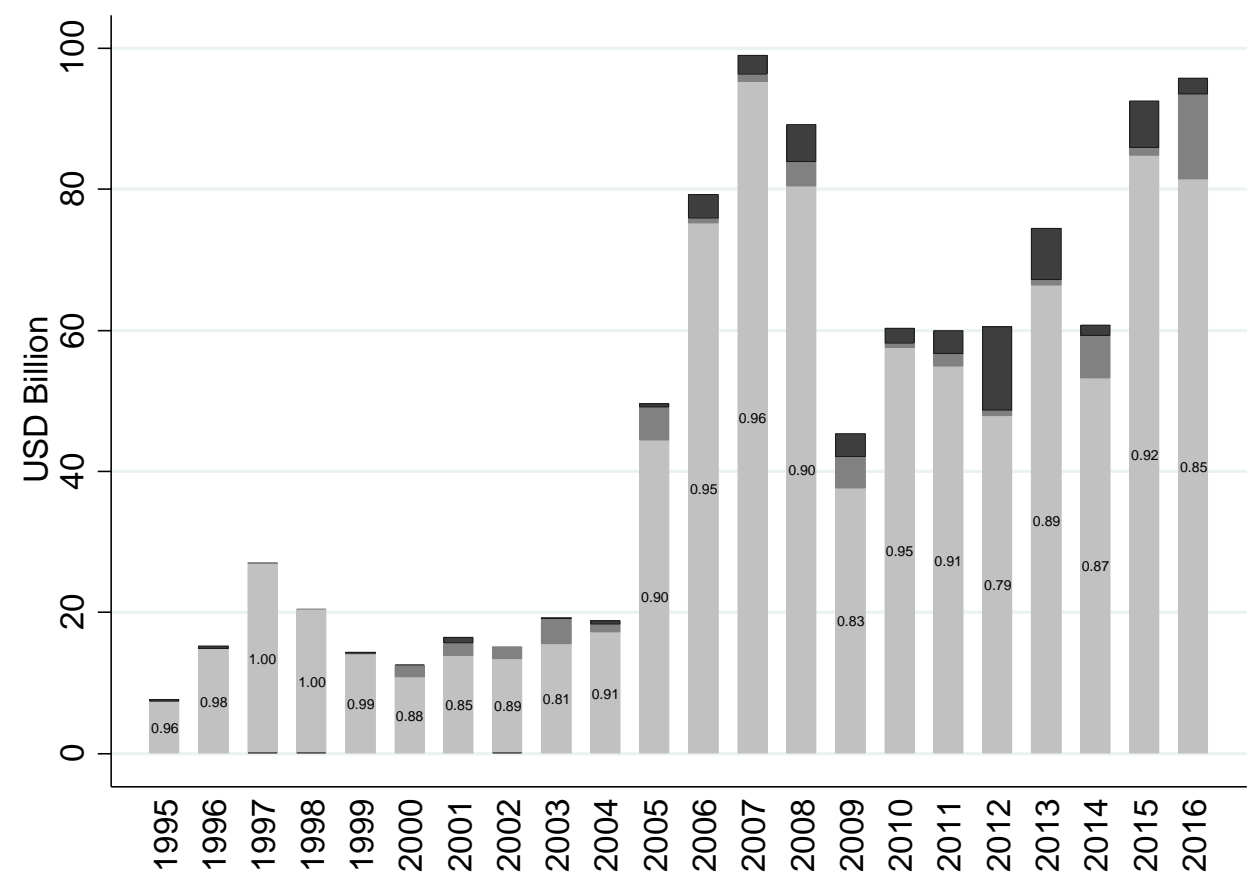

(b) Emerging America

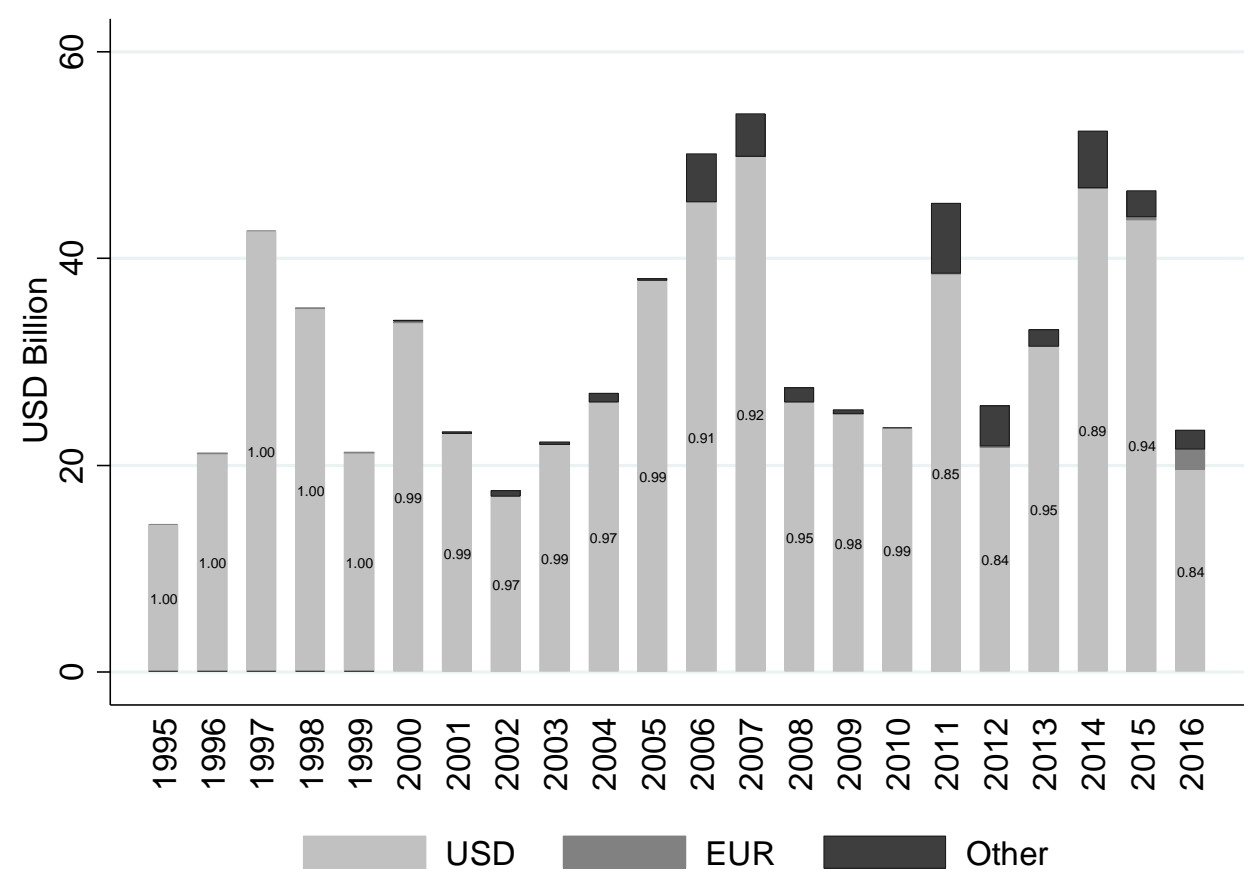




\section{(c) Emerging Asia}

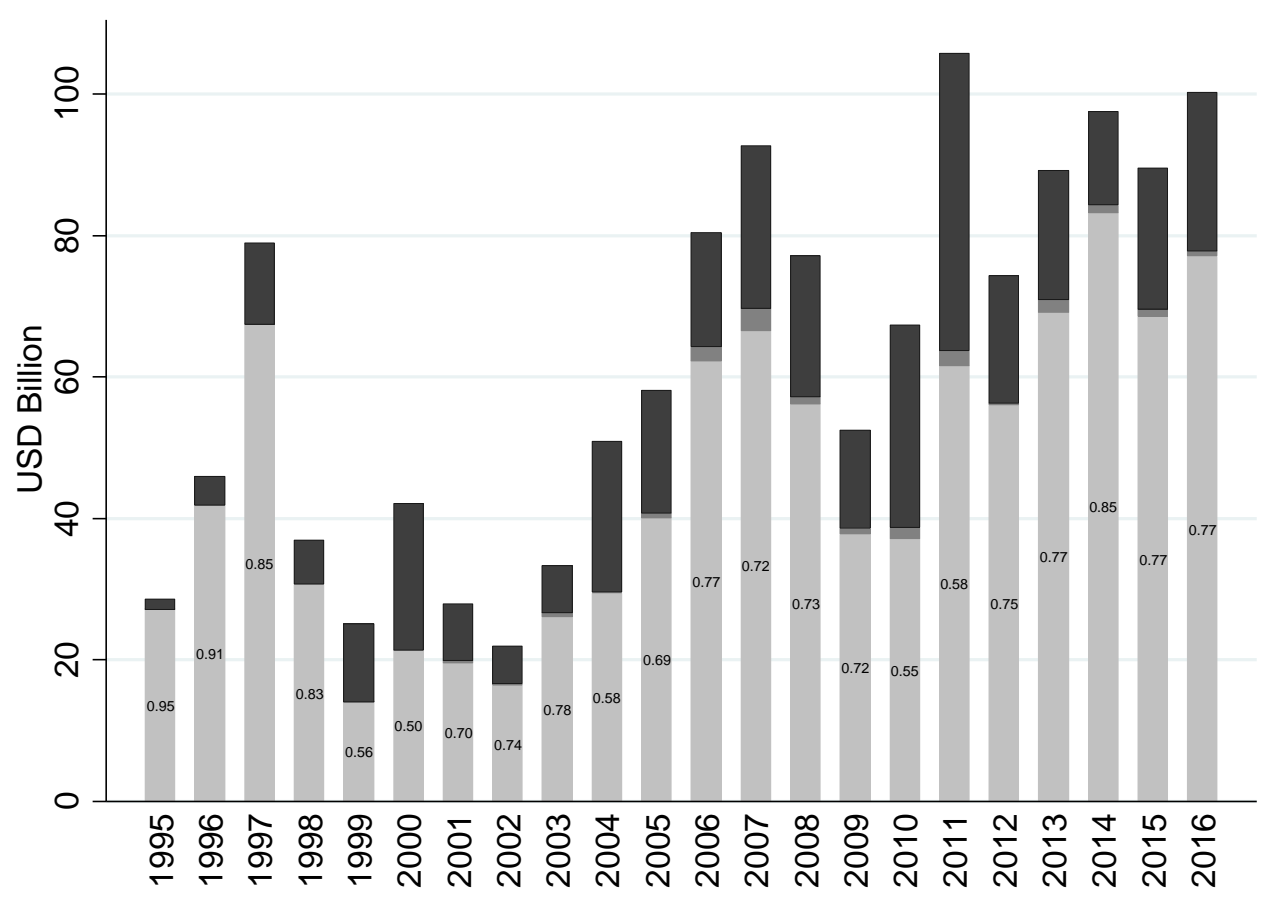

(d) Emerging Europe

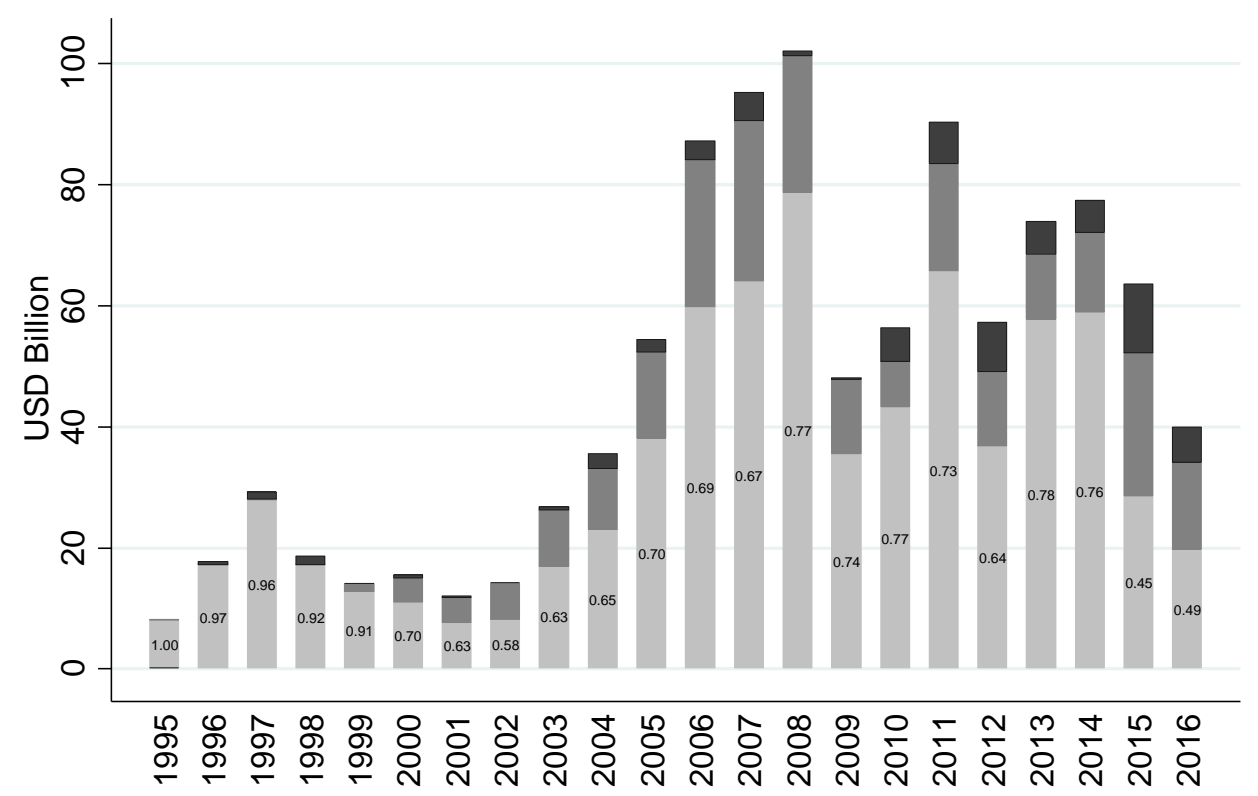

USD

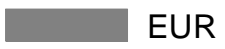

Other

Note: The labels of the light grey (lower) bars correspond to the share of loans in each year that are denominated in U.S. dollars. Country groups are based on the BIS classification. Offshore centers are excluded from the sample. Source: Authors' calculations based on IMF and BIS data. 


\section{FIGURE V}

LENDING TO EMES BY FOREIGN DME BANKS VS. LOCAL BANKS

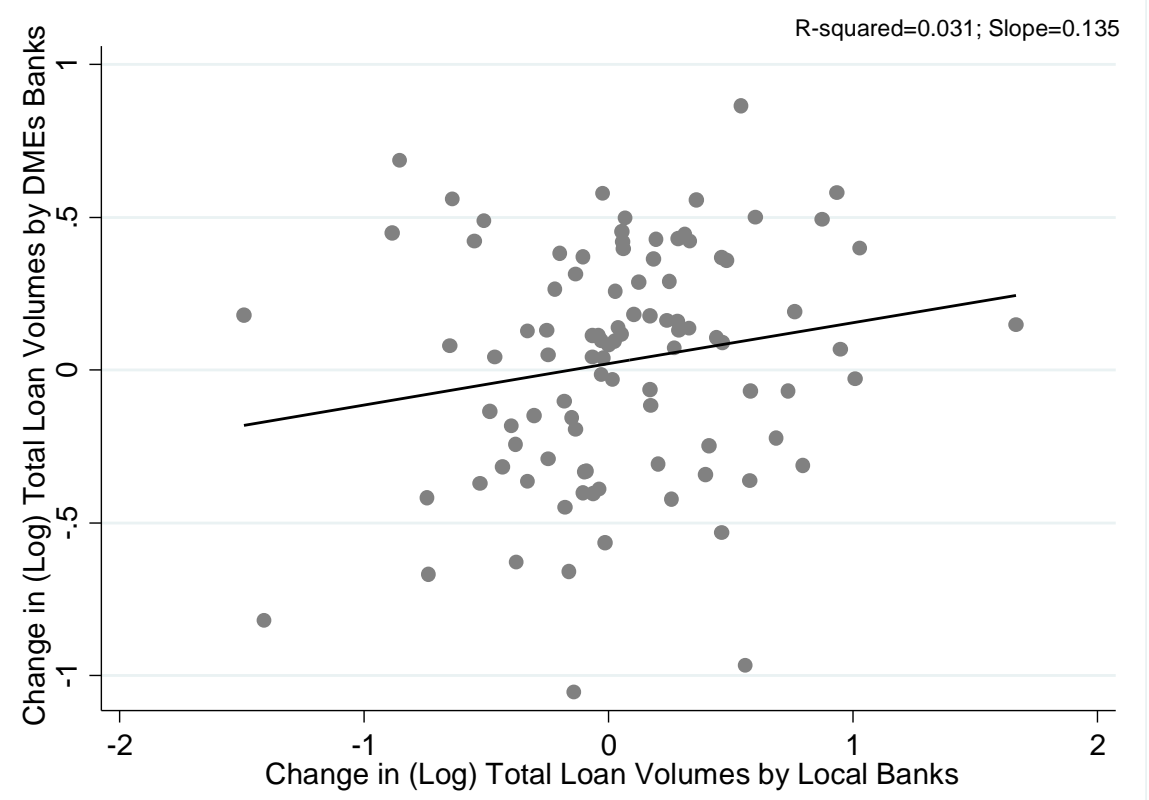

Note: The figure depicts the changes in the (logarithm of) syndicated loan volumes to EME borrowers by local lenders (horizontal axis) and DME/foreign lenders (vertical axis). Each data point corresponds to the change in lending by local and foreign banks in one quarter. The sample covers the period from 1990:Q1 to 2016:Q3.

Source: Authors' calculations based on DealScan data. 
TABLE I - COUNTRY-LEVEL INFORMATION ON SYNDICATED CROSS-BORDER LOANS TO EMES

\begin{tabular}{|c|c|c|c|c|c|c|c|}
\hline \multirow[t]{2}{*}{ Country } & \multirow[t]{2}{*}{ \# Firms } & \multirow[t]{2}{*}{ \# Loans } & \multirow{2}{*}{$\begin{array}{l}\text { Total Trade } \\
\text { (\% of GDP) }\end{array}$} & \multirow{2}{*}{$\begin{array}{c}\text { U.S. Trade } \\
\text { (\% of Total } \\
\text { Trade) }\end{array}$} & \multicolumn{3}{|c|}{ Share of Loans in } \\
\hline & & & & & USD & EUR & Other \\
\hline \multicolumn{8}{|l|}{ Africa } \\
\hline Algeria & 7 & 15 & $47.6 \%$ & $13.6 \%$ & $93.3 \%$ & $6.7 \%$ & $0.0 \%$ \\
\hline Angola & 9 & 35 & $72.1 \%$ & $29.5 \%$ & $82.9 \%$ & $8.6 \%$ & $8.6 \%$ \\
\hline Burundi & 1 & 3 & $27.3 \%$ & $3.2 \%$ & $100.0 \%$ & $0.0 \%$ & $0.0 \%$ \\
\hline Cameroon & 8 & 13 & $29.9 \%$ & $6.5 \%$ & $69.2 \%$ & $30.8 \%$ & $0.0 \%$ \\
\hline Congo & 2 & 5 & $35.5 \%$ & $3.4 \%$ & $100.0 \%$ & $0.0 \%$ & $0.0 \%$ \\
\hline Egypt & 62 & 141 & $25.6 \%$ & $11.3 \%$ & $90.1 \%$ & $4.3 \%$ & $5.7 \%$ \\
\hline Gabon & 4 & 6 & $63.2 \%$ & $32.9 \%$ & $66.7 \%$ & $16.7 \%$ & $16.7 \%$ \\
\hline Ghana & 32 & 80 & $37.6 \%$ & $8.0 \%$ & $97.5 \%$ & $1.3 \%$ & $1.3 \%$ \\
\hline Guinea & 3 & 5 & $49.5 \%$ & $11.9 \%$ & $100.0 \%$ & $0.0 \%$ & $0.0 \%$ \\
\hline Iran & 17 & 51 & $26.6 \%$ & $1.6 \%$ & $74.5 \%$ & $23.5 \%$ & $2.0 \%$ \\
\hline Iraq & 3 & 6 & $61.3 \%$ & $15.1 \%$ & $50.0 \%$ & $0.0 \%$ & $50.0 \%$ \\
\hline Israel & 43 & 97 & $51.2 \%$ & $22.6 \%$ & $86.6 \%$ & $9.3 \%$ & $4.1 \%$ \\
\hline Ivory Coast & 16 & 23 & $60.2 \%$ & $6.7 \%$ & $91.3 \%$ & $4.3 \%$ & $4.3 \%$ \\
\hline Jordan & 19 & 23 & $78.8 \%$ & $9.1 \%$ & $87.0 \%$ & $0.0 \%$ & $13.0 \%$ \\
\hline Kenya & 20 & 28 & $34.8 \%$ & $5.5 \%$ & $82.1 \%$ & $10.7 \%$ & $7.1 \%$ \\
\hline Kuwait & 52 & 98 & $72.8 \%$ & $10.1 \%$ & $99.0 \%$ & $0.0 \%$ & $1.0 \%$ \\
\hline Liberia & 36 & 46 & $961.0 \%$ & $5.5 \%$ & $84.8 \%$ & $2.2 \%$ & $13.0 \%$ \\
\hline Mali & 5 & 15 & $37.7 \%$ & $2.8 \%$ & $33.3 \%$ & $66.7 \%$ & $0.0 \%$ \\
\hline Morocco & 13 & 16 & $45.1 \%$ & $5.3 \%$ & $81.3 \%$ & $18.8 \%$ & $0.0 \%$ \\
\hline Mozambique & 4 & 20 & $46.1 \%$ & $4.9 \%$ & $90.0 \%$ & $5.0 \%$ & $5.0 \%$ \\
\hline Namibia & 6 & 8 & $63.9 \%$ & $2.8 \%$ & $100.0 \%$ & $0.0 \%$ & $0.0 \%$ \\
\hline Nigeria & 51 & 84 & $28.9 \%$ & $25.6 \%$ & $96.4 \%$ & $0.0 \%$ & $3.6 \%$ \\
\hline Oman & 58 & 101 & $81.7 \%$ & $4.4 \%$ & $95.0 \%$ & $1.0 \%$ & $4.0 \%$ \\
\hline Qatar & 55 & 122 & $74.0 \%$ & $4.2 \%$ & $97.5 \%$ & $1.6 \%$ & $0.8 \%$ \\
\hline Saudi Arabia & 82 & 135 & $59.8 \%$ & $16.4 \%$ & $91.9 \%$ & $4.4 \%$ & $3.7 \%$ \\
\hline Senegal & 5 & 6 & $45.8 \%$ & $3.0 \%$ & $83.3 \%$ & $16.7 \%$ & $0.0 \%$ \\
\hline Seychelles & 1 & 5 & $92.8 \%$ & $3.2 \%$ & $80.0 \%$ & $20.0 \%$ & $0.0 \%$ \\
\hline South Africa & 127 & 321 & $25.2 \%$ & $8.7 \%$ & $73.5 \%$ & $5.3 \%$ & $21.2 \%$ \\
\hline Tanzania & 11 & 16 & $31.8 \%$ & $3.1 \%$ & $93.8 \%$ & $0.0 \%$ & $6.3 \%$ \\
\hline Togo & 1 & 2 & $54.5 \%$ & $2.7 \%$ & $50.0 \%$ & $50.0 \%$ & $0.0 \%$ \\
\hline Tunisia & 20 & 31 & $69.2 \%$ & $4.0 \%$ & $67.7 \%$ & $29.0 \%$ & $3.2 \%$ \\
\hline United Arab Emirates & 185 & 411 & $85.8 \%$ & $5.5 \%$ & $89.8 \%$ & $3.9 \%$ & $6.3 \%$ \\
\hline Zambia & 14 & 25 & $52.3 \%$ & $3.8 \%$ & $84.0 \%$ & $4.0 \%$ & $12.0 \%$ \\
\hline Zimbabwe & 11 & 16 & $57.4 \%$ & $5.0 \%$ & $100.0 \%$ & $0.0 \%$ & $0.0 \%$ \\
\hline $\begin{array}{l}\text { Total: } \\
\text { Americas }\end{array}$ & 994 & 2,009 & & & $87.2 \%$ & $5.5 \%$ & $7.3 \%$ \\
\hline Argentina & 196 & 372 & $19.4 \%$ & $13.1 \%$ & $95.7 \%$ & $0.3 \%$ & $4.0 \%$ \\
\hline Bolivia & 6 & 8 & $44.6 \%$ & $18.1 \%$ & $100.0 \%$ & $0.0 \%$ & $0.0 \%$ \\
\hline Brazil & 338 & 636 & $18.5 \%$ & $19.3 \%$ & $95.3 \%$ & $0.5 \%$ & $4.2 \%$ \\
\hline Chile & 207 & 417 & $48.9 \%$ & $18.0 \%$ & $96.6 \%$ & $0.2 \%$ & $3.1 \%$ \\
\hline Colombia & 91 & 158 & $23.2 \%$ & $34.9 \%$ & $96.8 \%$ & $0.0 \%$ & $3.2 \%$ \\
\hline Costa Rica & 12 & 15 & $64.2 \%$ & $39.7 \%$ & $100.0 \%$ & $0.0 \%$ & $0.0 \%$ \\
\hline Dominican Republic & 12 & 16 & $41.6 \%$ & $49.0 \%$ & $100.0 \%$ & $0.0 \%$ & $0.0 \%$ \\
\hline Ecuador & 9 & 10 & $39.6 \%$ & $36.7 \%$ & $100.0 \%$ & $0.0 \%$ & $0.0 \%$ \\
\hline El Salvador & 14 & 17 & $53.1 \%$ & $40.9 \%$ & $100.0 \%$ & $0.0 \%$ & $0.0 \%$ \\
\hline Guatemala & 13 & 16 & $44.4 \%$ & $38.8 \%$ & $100.0 \%$ & $0.0 \%$ & $0.0 \%$ \\
\hline Honduras & 4 & 12 & $54.9 \%$ & $43.5 \%$ & $100.0 \%$ & $0.0 \%$ & $0.0 \%$ \\
\hline Jamaica & 11 & 13 & $61.4 \%$ & $42.0 \%$ & $92.3 \%$ & $0.0 \%$ & $7.7 \%$ \\
\hline Mexico & 368 & 790 & $41.9 \%$ & $68.8 \%$ & $92.4 \%$ & $0.3 \%$ & $7.3 \%$ \\
\hline
\end{tabular}




\begin{tabular}{|c|c|c|c|c|c|c|c|}
\hline Nicaragua & 2 & 3 & $53.7 \%$ & $23.9 \%$ & $100.0 \%$ & $0.0 \%$ & $0.0 \%$ \\
\hline Paraguay & 3 & 4 & $49.6 \%$ & $7.1 \%$ & $100.0 \%$ & $0.0 \%$ & $0.0 \%$ \\
\hline Peru & 89 & 118 & $30.3 \%$ & $25.1 \%$ & $97.5 \%$ & $0.0 \%$ & $2.5 \%$ \\
\hline Trinidad and Tobago & 12 & 18 & $80.2 \%$ & $44.5 \%$ & $100.0 \%$ & $0.0 \%$ & $0.0 \%$ \\
\hline Uruguay & 14 & 16 & $31.1 \%$ & $9.1 \%$ & $100.0 \%$ & $0.0 \%$ & $0.0 \%$ \\
\hline Venezuela & 52 & 92 & $41.6 \%$ & $41.4 \%$ & $96.7 \%$ & $0.0 \%$ & $3.3 \%$ \\
\hline $\begin{array}{ll} & \text { Total: } \\
\text { Asia } & \end{array}$ & 1,505 & 2,731 & & & $95.2 \%$ & $0.3 \%$ & $4.6 \%$ \\
\hline Armenia & 5 & 9 & $57.9 \%$ & $8.9 \%$ & $88.9 \%$ & $11.1 \%$ & $0.0 \%$ \\
\hline Azerbaijan & 21 & 59 & $63.3 \%$ & $4.4 \%$ & $93.2 \%$ & $5.1 \%$ & $1.7 \%$ \\
\hline Bangladesh & 21 & 30 & $24.5 \%$ & $11.3 \%$ & $86.7 \%$ & $0.0 \%$ & $13.3 \%$ \\
\hline Cambodia & 10 & 14 & $69.3 \%$ & $12.2 \%$ & $85.7 \%$ & $0.0 \%$ & $14.3 \%$ \\
\hline China & 1,051 & 1,704 & $61.8 \%$ & $14.1 \%$ & $75.4 \%$ & $0.2 \%$ & $24.5 \%$ \\
\hline Georgia & 7 & 10 & $52.5 \%$ & $5.5 \%$ & $100.0 \%$ & $0.0 \%$ & $0.0 \%$ \\
\hline India & 482 & 1,120 & $21.6 \%$ & $11.6 \%$ & $82.9 \%$ & $2.0 \%$ & $15.2 \%$ \\
\hline Indonesia & 655 & 1,224 & $37.9 \%$ & $12.2 \%$ & $92.6 \%$ & $0.7 \%$ & $6.8 \%$ \\
\hline Kazakhstan & 60 & 174 & $59.4 \%$ & $2.9 \%$ & $93.7 \%$ & $4.6 \%$ & $1.7 \%$ \\
\hline Korea (South) & 429 & 1,187 & $61.5 \%$ & $19.1 \%$ & $83.9 \%$ & $2.8 \%$ & $13.3 \%$ \\
\hline Malaysia & 339 & 523 & $132.7 \%$ & $15.0 \%$ & $63.5 \%$ & $0.8 \%$ & $35.8 \%$ \\
\hline Mongolia & 14 & 23 & $51.2 \%$ & $5.2 \%$ & $91.3 \%$ & $0.0 \%$ & $8.7 \%$ \\
\hline Myanmar & 4 & 9 & $44.1 \%$ & $2.8 \%$ & $100.0 \%$ & $0.0 \%$ & $0.0 \%$ \\
\hline Pakistan & 56 & 97 & $26.3 \%$ & $11.4 \%$ & $52.6 \%$ & $0.0 \%$ & $47.4 \%$ \\
\hline Papua New Guinea & 12 & 21 & $55.5 \%$ & $4.0 \%$ & $85.7 \%$ & $0.0 \%$ & $14.3 \%$ \\
\hline Philippines & 171 & 351 & $55.5 \%$ & $21.8 \%$ & $76.6 \%$ & $0.3 \%$ & $23.1 \%$ \\
\hline Sri Lanka & 21 & 49 & $47.9 \%$ & $14.1 \%$ & $91.8 \%$ & $0.0 \%$ & $8.2 \%$ \\
\hline Tajikistan & 7 & 10 & $100.7 \%$ & $1.9 \%$ & $100.0 \%$ & $0.0 \%$ & $0.0 \%$ \\
\hline Thailand & 411 & 801 & $83.5 \%$ & $13.1 \%$ & $78.5 \%$ & $0.9 \%$ & $20.6 \%$ \\
\hline Turkmenistan & 6 & 8 & $50.8 \%$ & $4.1 \%$ & $75.0 \%$ & $0.0 \%$ & $25.0 \%$ \\
\hline Uzbekistan & 13 & 21 & $40.6 \%$ & $3.5 \%$ & $76.2 \%$ & $9.5 \%$ & $14.3 \%$ \\
\hline Vietnam & 126 & 235 & $86.2 \%$ & $6.1 \%$ & $93.2 \%$ & $0.9 \%$ & $6.0 \%$ \\
\hline $\begin{array}{ll} & \text { Total: } \\
\text { Europe } & \\
\end{array}$ & 4,047 & 7,679 & & & $81.3 \%$ & $1.2 \%$ & $17.5 \%$ \\
\hline Belarus & 15 & 38 & $100.6 \%$ & $1.5 \%$ & $71.1 \%$ & $26.3 \%$ & $2.6 \%$ \\
\hline Bulgaria & 40 & 69 & $79.3 \%$ & $2.5 \%$ & $4.3 \%$ & $92.8 \%$ & $2.9 \%$ \\
\hline Croatia & 55 & 146 & $57.3 \%$ & $2.4 \%$ & $32.9 \%$ & $63.0 \%$ & $4.1 \%$ \\
\hline Czech Republic & 118 & 203 & $117.9 \%$ & $2.3 \%$ & $38.4 \%$ & $23.2 \%$ & $38.4 \%$ \\
\hline Hungary & 97 & 243 & $102.5 \%$ & $2.8 \%$ & $48.1 \%$ & $45.7 \%$ & $6.2 \%$ \\
\hline Kosovo & 5 & 10 & $20.7 \%$ & $0.5 \%$ & $0.0 \%$ & $100.0 \%$ & $0.0 \%$ \\
\hline Poland & 128 & 271 & $51.8 \%$ & $2.4 \%$ & $37.3 \%$ & $35.8 \%$ & $26.9 \%$ \\
\hline Romania & 94 & 169 & $54.4 \%$ & $3.1 \%$ & $43.8 \%$ & $47.3 \%$ & $8.9 \%$ \\
\hline Russia & 390 & 1,166 & $39.5 \%$ & $5.2 \%$ & $87.7 \%$ & $7.5 \%$ & $4.9 \%$ \\
\hline Serbia & 7 & 8 & $52.0 \%$ & $1.7 \%$ & $12.5 \%$ & $87.5 \%$ & $0.0 \%$ \\
\hline Turkey & 231 & 918 & $29.6 \%$ & $7.1 \%$ & $84.6 \%$ & $13.6 \%$ & $1.7 \%$ \\
\hline Ukraine & 79 & 202 & $74.0 \%$ & $3.3 \%$ & $92.1 \%$ & $6.9 \%$ & $1.0 \%$ \\
\hline Total: & 1,338 & 3,443 & & & $70.7 \%$ & $21.6 \%$ & $7.7 \%$ \\
\hline
\end{tabular}

Note: The table is based on syndicated cross-border loans issued from 1990:Q1 to 2016:Q3. Country groups are based on the BIS classification. Offshore centers are excluded from the sample. We also exclude countries with only non-repeat borrowers and four countries with missing trade data. Currency shares are based on loan counts. Trade is the average value of the sum of imports and exports of goods as a percentage of GDP. U.S. Trade is the average value of traded goods (imports plus exports) with the United States as a percentage of total traded goods. Data on trade and GDP are compiled from the IMF. 


\section{TABLE II - CURRENCY BREAKDOWN OF CROSS-BORDER BANK LOANS}

Panel A: Cross-Border Loan Issuance by Industry and Region, 1990:Q1-2016:Q3

\begin{tabular}{lllll}
\hline & \multicolumn{3}{c}{ U.S. Dollar Shares } \\
\cline { 2 - 4 } \multicolumn{1}{c}{ Region: } & $\begin{array}{l}\text { EME: } \\
\text { Africa }\end{array}$ & $\begin{array}{l}\text { EME: } \\
\text { Americas }\end{array}$ & $\begin{array}{l}\text { EME: } \\
\text { Asia }\end{array}$ & $\begin{array}{l}\text { EME: } \\
\text { Europe }\end{array}$ \\
\hline Tradable: & & & & \\
$\quad$ Agriculture, Forestry and Fishing & $75.6 \%$ & $95.9 \%$ & $80.6 \%$ & $86.4 \%$ \\
$\quad$ Mining & $91.2 \%$ & $97.4 \%$ & $92.9 \%$ & $85.4 \%$ \\
$\quad$ Manufacturing & $82.5 \%$ & $95.6 \%$ & $73.8 \%$ & $63.3 \%$ \\
Non-Tradable: & & & & \\
$\quad$ Construction & $84.4 \%$ & $79.6 \%$ & $64.8 \%$ & $31.5 \%$ \\
$\quad$ Transp., Communic., Electric, Gas, Sanitary & $82.8 \%$ & $95.9 \%$ & $77.5 \%$ & $49.6 \%$ \\
$\quad$ Wholesale Trade & $88.0 \%$ & $88.9 \%$ & $72.6 \%$ & $42.4 \%$ \\
$\quad$ Retail Trade & $80.0 \%$ & $90.5 \%$ & $56.2 \%$ & $34.7 \%$ \\
$\quad$ Finance, Insurance, Real Estate & $91.5 \%$ & $98.7 \%$ & $79.1 \%$ & $80.6 \%$ \\
$\quad$ Services & $67.4 \%$ & $92.9 \%$ & $68.2 \%$ & $33.6 \%$ \\
$\quad$ Public Administration & $72.3 \%$ & $85.0 \%$ & $49.7 \%$ & $69.0 \%$ \\
\hline
\end{tabular}

Panel B: Outstanding Cross-Border Loans as of 2016:Q3

\begin{tabular}{lllllllllll}
\hline & \multicolumn{4}{c}{$\begin{array}{c}\text { Cross-Border Loans } \\
\text { (Source: DealScan) }\end{array}$} & & \multicolumn{4}{c}{$\begin{array}{c}\text { Cross-Border "Bank Claims" } \\
\text { (Source: BIS) }\end{array}$} \\
\cline { 2 - 11 } Currency: & USD & EUR & GBP & JPY & Other & USD & EUR & GBP & JPY & Other \\
\hline Region: & & & & & & & & & & \\
EME: Africa & $88.8 \%$ & $5.3 \%$ & $0.1 \%$ & $0.8 \%$ & $4.9 \%$ & $65.5 \%$ & $12.7 \%$ & $3.9 \%$ & $1.0 \%$ & $16.9 \%$ \\
EME: Americas & $91.3 \%$ & $1.1 \%$ & $0.0 \%$ & $0.7 \%$ & $6.9 \%$ & $75.6 \%$ & $4.4 \%$ & $0.2 \%$ & $1.7 \%$ & $18.2 \%$ \\
EME: Asia & $69.7 \%$ & $1.3 \%$ & $0.7 \%$ & $4.2 \%$ & $24.0 \%$ & $51.9 \%$ & $5.0 \%$ & $0.3 \%$ & $1.3 \%$ & $41.5 \%$ \\
EME: Europe & $56.0 \%$ & $30.9 \%$ & $0.0 \%$ & $0.6 \%$ & $12.5 \%$ & $31.9 \%$ & $38.8 \%$ & $0.5 \%$ & $1.1 \%$ & $27.7 \%$ \\
DME & $69.8 \%$ & $19.7 \%$ & $5.0 \%$ & $0.7 \%$ & $4.8 \%$ & $43.3 \%$ & $36.9 \%$ & $4.9 \%$ & $4.9 \%$ & $10.1 \%$ \\
\hline
\end{tabular}

Note: Country groups are based on the BIS classification. Offshore centers are excluded from the sample. Industry classification is based on the 1-digit SIC code as reported in DealScan. Figures in Panel A are based on all loans issued between 1990:Q1 and 2016:Q3 and reported in DealScan. In Panel B, we report figures computed from our DealScan sample, and, for comparison, figures compiled from BIS data. DealScan tracks loan issuance; thus, statistics reported in the first five columns of Panel B are based on the estimated volume of outstanding claims as of 2016:Q3. Note that the BIS data include all outstanding cross-border claims held by banks (including equities and bonds). 


\section{TABLE III - GLOBAL BANKS’ CROSS-BORDER DOLLAR LENDING IN EMERGING MARKETS}

Panel A: Full Samples

\begin{tabular}{|c|c|c|c|c|c|c|c|}
\hline & $(1)$ & $(2)$ & $(3)$ & $(4)$ & $(5)$ & $\begin{array}{l}\text { Pre-ZLB } \\
\text { Period } \\
(6) \\
\end{array}$ & $\begin{array}{l}\text { ZLB } \\
\text { Period } \\
(7) \\
\end{array}$ \\
\hline U.S. Interest Rate & $\begin{array}{l}-0.144 * * * \\
(-11.49)\end{array}$ & -- & -- & -- & -- & -- & -- \\
\hline U.S. Interest Rate * DME & -- & $\begin{array}{l}-0.090 * * * \\
(-9.98)\end{array}$ & -- & -- & -- & -- & -- \\
\hline U.S. Interest Rate * EME & -- & $\begin{array}{l}-0.194 * * * \\
(-9.66)\end{array}$ & $\begin{array}{l}-0.077 * * * \\
(-7.54)\end{array}$ & $\begin{array}{l}-0.081 * * * \\
(-7.69)\end{array}$ & $\begin{array}{l}-0.164 * * * \\
(-12.71)\end{array}$ & $\begin{array}{l}-0.074 * * \\
(-3.41)\end{array}$ & -- \\
\hline U.S. Term Spread * EME & -- & -- & -- & -- & $\begin{array}{l}-0.158 * * * \\
(-6.80)\end{array}$ & $\begin{array}{l}-0.092 * * \\
(-3.08)\end{array}$ & -- \\
\hline U.S. Shadow Rate * EME & -- & -- & -- & -- & -- & -- & $\begin{array}{l}-0.068 * * \\
(-2.75)\end{array}$ \\
\hline EME & -- & $\begin{array}{l}-0.951 * * * \\
(13.43)\end{array}$ & -- & -- & -- & -- & -- \\
\hline \multicolumn{8}{|l|}{ Fixed Effects: } \\
\hline Quarter $\left(D_{t}\right)$ & -- & -- & Yes & -- & -- & -- & -- \\
\hline $\operatorname{Bank}\left(D_{j}\right)$ & -- & -- & Yes & -- & -- & -- & -- \\
\hline Borrower $\left(D_{i}\right)$ & -- & -- & Yes & Yes & Yes & Yes & Yes \\
\hline Bank * Quarter $\left(D_{i t}\right)$ & -- & -- & -- & Yes & Yes & Yes & Yes \\
\hline Observations & 171,276 & 170,518 & 161,596 & 158,188 & 158,188 & 111,918 & 38,909 \\
\hline$R$-squared & 0.067 & 0.301 & 0.821 & 0.830 & 0.830 & 0.839 & 0.820 \\
\hline
\end{tabular}

Panel B: Dollar Lending by Banks with Low Exposure to the U.S. Economy

\begin{tabular}{|c|c|c|c|c|c|c|}
\hline \multirow{2}{*}{$\begin{array}{l}\text { Banks' Loan Exposure to U.S.: } \\
\text { Borrowers: }\end{array}$} & \multirow[t]{2}{*}{$<10 \%$} & \multirow[t]{2}{*}{$<5 \%$} & \multirow{2}{*}{$\begin{array}{l}\quad<5 \% \\
\text { Non- } \\
\text { Tradable } \\
\text { Industry }\end{array}$} & $<5 \%$ & $<5 \%$ & $<5 \%$ \\
\hline & & & & $\begin{array}{l}\text { Sectors with } \\
\text { Low Export } \\
\text { Share } \\
(4)\end{array}$ & $\begin{array}{l}\text { Country with } \\
\text { Low Trade } \\
\text { Overall } \\
(5) \\
\end{array}$ & $\begin{array}{l}\text { Country with } \\
\text { Low Trade } \\
\text { with U.S. } \\
(6)\end{array}$ \\
\hline U.S. Interest Rate * EME & $\begin{array}{l}-0.159 * * * \\
(-5.58)\end{array}$ & $\begin{array}{l}-0.078 * \\
(-1.79)\end{array}$ & $\begin{array}{l}-0.091 * * \\
(-1.99)\end{array}$ & $\begin{array}{l}-0.181^{* * *} \\
(-2.69)\end{array}$ & $\begin{array}{l}-0.092 * * \\
(-2.09)\end{array}$ & $\begin{array}{l}-0.348 * * * \\
(-5.71)\end{array}$ \\
\hline U.S. Term Spread * EME & $\begin{array}{l}-0.186^{* * *} \\
(-4.29)\end{array}$ & $\begin{array}{l}-0.112^{*} \\
(-1.76)\end{array}$ & $\begin{array}{l}-0.135^{* *} \\
(-2.02)\end{array}$ & $\begin{array}{l}-0.073 \\
(-0.26)\end{array}$ & $\begin{array}{l}-0.092 \\
(-1.51)\end{array}$ & $\begin{array}{l}-0.517 * * * \\
(-5.97)\end{array}$ \\
\hline Fixed Effects: & & & & & & \\
\hline Borrower $\left(D_{i}\right)$ & Yes & Yes & Yes & Yes & Yes & Yes \\
\hline Bank * Quarter $\left(D_{i t}\right)$ & Yes & Yes & Yes & Yes & Yes & Yes \\
\hline Observations & 28,749 & 11,147 & 9,158 & 2,639 & 4,841 & 3,807 \\
\hline$R$-squared & 0.874 & 0.897 & 0.905 & 0.930 & 0.902 & 0.931 \\
\hline
\end{tabular}

Note: The dependent variable is the logarithm of the dollar loan amount originated by a given bank to a given firm in a given quarter. U.S. Interest Rate is the federal funds rate (in percent). U.S. Term Spread is the difference between the 10-year U.S. Treasury yield and the federal funds rate (in percentage points), that is, the slope of the yield curve. Shadow Rate is a single measure of monetary policy during the zero-lower bound period constructed by Wu and Xia (2016). EME is a dummy variable that equals one if the firm is located in an emerging market country (as defined by BIS), and zero otherwise. DME is a dummy that equals one if the borrower is located in a developed market country, and zero otherwise. The sample in columns (1)-(5), both panels, covers the period from 1990:Q1 through 2016:Q3. The sample in Panel A, column (6) covers the period from 1990:Q1 through 2008:Q3. Panel A, column (7), shows that our main result holds during the period when the federal funds rate was at the zero lower bound (2008:Q4-2015:Q3). Panel B replicates the results in Panel A, column (5), while focusing on non-U.S. lenders and non-U.S. borrowers that are unlikely to be connected to the U.S. economy. Non-U.S. Banks with low U.S. exposure are 
identified based on the number of loans to U.S. borrowers in the entire sample (relative to all loans). Column (3) contains only EME borrowers from the non-tradable sectors based on the SIC 1-digit classification as reported in DealScan. Column (4) contains only EME borrowers from sectors that produce goods and services with an export share below the $25^{\text {th }}$ percentile (based on the distribution of export shares of all goods and services for each borrower country). Column (5) contains only loans to EME borrowers from countries with an average total trade-to-GDP share below the $25^{\text {th }}$ percentile of the cross-country distribution (see Table I). Column (6) contains only loans to EME borrowers from countries with the average U.S. trade share (relative to total trade) below the $25^{\text {th }}$ percentile of the cross-country distribution (see Table I). Robust $t$-statistics are in parentheses. Standard errors are clustered at the quarter level. ***, **, and * indicate statistical significance at the $1 \%$, 5\%, and $10 \%$ level, respectively. 
TABle IV - U.S. Monetary Policy AND Global BANKS’ LeNDing IN High-Yield MaRKets

\begin{tabular}{|c|c|c|c|c|c|c|c|c|}
\hline & \multicolumn{8}{|c|}{ "High-Yield Market" Defined Using: } \\
\hline & $\begin{array}{l}\text { GDP } \\
\text { Growth } \\
(1)\end{array}$ & $\begin{array}{l}\text { GDP } \\
\text { Growth } \\
(2)\end{array}$ & $\begin{array}{l}\text { Interest Rate } \\
\text { Spread } \\
(3)\end{array}$ & $\begin{array}{l}\text { Interest Rate } \\
\text { Spread } \\
(4)\end{array}$ & $\begin{array}{l}\text { Equity } \\
\text { Returns } \\
\text { (5) }\end{array}$ & $\begin{array}{l}\text { Equity } \\
\text { Returns } \\
(6)\end{array}$ & $\begin{array}{l}\text { Country } \\
\text { Rating } \\
(7)\end{array}$ & $\begin{array}{l}\text { Country } \\
\text { Rating } \\
(8)\end{array}$ \\
\hline U.S. Interest Rate * High-Yield Market & $\begin{array}{l}-0.002 * * \\
(-2.05)\end{array}$ & $\begin{array}{l}-0.006^{* * *} \\
(-3.00)\end{array}$ & $\begin{array}{l}-0.003^{* * *} \\
(-5.65)\end{array}$ & $\begin{array}{l}-0.004 * * * \\
(-3.65)\end{array}$ & $\begin{array}{l}-0.024 * \\
(-1.68)\end{array}$ & $\begin{array}{l}-0.031 \\
(-0.80)\end{array}$ & $\begin{array}{l}-0.007^{* * *} \\
(-6.45)\end{array}$ & $\begin{array}{l}-0.014^{* * *} \\
(-7.92)\end{array}$ \\
\hline U.S. Term Spread * High-Yield Market & -- & $\begin{array}{l}-0.007^{*} \\
(-1.97)\end{array}$ & -- & $\begin{array}{l}-0.001 \\
(-0.92)\end{array}$ & -- & $\begin{array}{l}-0.013 \\
(-0.20)\end{array}$ & -- & $\begin{array}{l}-0.012 * * * \\
(-4.49)\end{array}$ \\
\hline High-Yield Market & $\begin{array}{l}0.014^{* * *} \\
(2.71)\end{array}$ & $\begin{array}{l}0.036 * * * \\
(3.08)\end{array}$ & $\begin{array}{l}0.014^{* * * *} \\
(5.36)\end{array}$ & $\begin{array}{l}0.019 * * * \\
(2.91)\end{array}$ & $\begin{array}{l}0.025 \\
(0.35)\end{array}$ & $\begin{array}{l}0.065 \\
(0.31)\end{array}$ & $\begin{array}{l}-0.063 * * * \\
(-5.23)\end{array}$ & $\begin{array}{l}-0.010 \\
(-0.69)\end{array}$ \\
\hline \multicolumn{9}{|l|}{ Fixed Effects: } \\
\hline $\begin{array}{l}\text { Borrower }\left(D_{i}\right) \\
\text { Bank * Quarter }\left(D_{j t}\right) \\
\text { Observations }\end{array}$ & $\begin{array}{l}\text { Yes } \\
\text { Yes } \\
151,702\end{array}$ & $\begin{array}{l}\text { Yes } \\
\text { Yes } \\
151,702\end{array}$ & $\begin{array}{l}\text { Yes } \\
\text { Yes } \\
136,691\end{array}$ & $\begin{array}{l}\text { Yes } \\
\text { Yes } \\
136,691\end{array}$ & $\begin{array}{l}\text { Yes } \\
\text { Yes } \\
136,531\end{array}$ & $\begin{array}{l}\text { Yes } \\
\text { Yes } \\
136,531\end{array}$ & $\begin{array}{l}\text { Yes } \\
\text { Yes } \\
132,246\end{array}$ & $\begin{array}{l}\text { Yes } \\
\text { Yes } \\
132,246\end{array}$ \\
\hline$R$-squared & 0.825 & 0.825 & 0.822 & 0.822 & 0.804 & 0.804 & 0.811 & 0.812 \\
\hline
\end{tabular}

Note: The dependent variable is the logarithm of the dollar loan amount originated by a given bank to a given firm in a given quarter. GDP Growth, , Interest Rate Spread, Equity Returns, and Country Rating describe the home country of the borrower and correspond to lagged values of GDP growth, the spread between the local EME interest rate and the U.S. federal funds rate, stock-market index growth, and the sovereign debt rating ("AAA"=1, "AA+"=2, etc.). Growth rates are in percentage terms. As before, U.S. Interest Rate is the federal funds rate (in percent), and U.S. Term Spread is the difference between the 10-year U.S. Treasury yield and the federal funds rate (in percentage points). Robust $t$ statistics are in parentheses. Standard errors are clustered at the quarter level. ***, **, and * indicate statistical significance at the $1 \%, 5 \%$, and $10 \%$ level, respectively. 
TABle V - Specialness of U.S. Monetary Policy For Cross-Border Dollar Credit

\begin{tabular}{|c|c|c|c|c|c|}
\hline \multirow[t]{3}{*}{ Loan Currency: } & \multirow[t]{2}{*}{ USD } & \multirow[t]{3}{*}{ USD } & USD & USD & \multirow{3}{*}{$\begin{array}{c}\text { EUR } \\
\text { U.S. Banks, } \\
\text { Non-EU Borrowers } \\
(5) \\
\end{array}$} \\
\hline & & & \multicolumn{2}{|c|}{$\begin{array}{c}\text { Non-U.S. Banks, } \\
\text { Non-U.S. Borrowers }\end{array}$} & \\
\hline & $(1)$ & & (3) & $(4)$ & \\
\hline Euro Interest Rate * EME & $\begin{array}{l}-0.147 * * * \\
(-7.82)\end{array}$ & $\begin{array}{l}-0.018 \\
(-0.57)\end{array}$ & $\begin{array}{l}-0.034 \\
(-0.86)\end{array}$ & -- & $\begin{array}{c}-0.228 * * \\
(-2.37)\end{array}$ \\
\hline Euro Term Spread * EME & $\begin{array}{l}-0.036 \\
(-1.25)\end{array}$ & $\begin{array}{l}0.030 \\
(1.10)\end{array}$ & $\begin{array}{l}0.046 \\
(1.17)\end{array}$ & -- & $\begin{array}{l}-0.136 \\
(-0.71)\end{array}$ \\
\hline U.S. Interest Rate * EME & -- & $\begin{array}{l}-0.191 * * * \\
(-5.64)\end{array}$ & $\begin{array}{c}-0.187 * * * \\
(-4.00)\end{array}$ & $\begin{array}{c}-0.196 * * * \\
(-4.05)\end{array}$ & $\begin{array}{l}-0.029 \\
(-0.21)\end{array}$ \\
\hline U.S. Term Spread * EME & -- & $\begin{array}{l}-0.223 * * * \\
(-5.34)\end{array}$ & $\begin{array}{c}-0.263 * * * \\
(-4.42)\end{array}$ & $\begin{array}{c}-0.343 * * * \\
(-4.21)\end{array}$ & $\begin{array}{l}-0.136 \\
(-0.71)\end{array}$ \\
\hline Fixed Effects: & & & & & \\
\hline Borrower $\left(D_{i}\right)$ & Yes & Yes & Yes & Yes & Yes \\
\hline Bank * Quarter $\left(D_{j t}\right)$ & Yes & Yes & Yes & Yes & Yes \\
\hline Observations & 113,277 & 113,277 & 51,091 & 16,809 & 210 \\
\hline$R$-squared & 0.825 & 0.826 & 0.843 & 0.887 & 0.940 \\
\hline
\end{tabular}

Note: This table highlights the special role of U.S. monetary police for global dollar credit. The dependent variable is the logarithm of the loan amount originated by a given bank to a given firm in a given quarter. Euro Interest Rate is the overnight rate EONIA (in percent). Euro Term Spread is the difference between the 10-year generic euro-area bond yield and the euro overnight rate (in percentage points). U.S. Interest Rate is the federal funds rate (in percent). U.S. Term Spread is the difference between the 10-year U.S. Treasury yield and the federal funds rate (in percentage points). Columns (3) and (4) exclude U.S. banks and U.S. borrowers from the sample. Column (4) includes only quarters where U.S. monetary policy was easing and ECB monetary policy was tightening (or vice versa). Column (5) looks at euro-denominated loans by U.S. firms to non-EU borrowers. The sample covers the period from 1999:Q1 (introduction of the euro) until 2016:Q3. Robust $t$-statistics are in parentheses. Standard errors are clustered at the quarter level. ***, **, and * indicate statistical significance at the $1 \%$, 5\%, and $10 \%$ level, respectively. 
TABLE VI - BIS Cross-Border Claims By BANKS From DeVeloped COUNTRIES

\begin{tabular}{|c|c|c|c|c|c|c|c|}
\hline \multirow[t]{2}{*}{ Dependent Variable: } & \multicolumn{5}{|c|}{ (Log) Claims on Firms (Nonbank Private Sector) } & \multicolumn{2}{|c|}{ (Log) Claims on Banks } \\
\hline & $(1)$ & $(2)$ & (3) & $(4)$ & (5) & (6) & $(7)$ \\
\hline U.S. Interest Rate & $\begin{array}{l}-0.095^{* * *} \\
(-5.63)\end{array}$ & -- & -- & -- & -- & -- & -- \\
\hline U.S. Interest Rate * DME & -- & $\begin{array}{l}-0.011 \\
(-0.60)\end{array}$ & -- & -- & -- & -- & -- \\
\hline U.S. Interest Rate * EME & -- & $\begin{array}{l}-0.129 * * * \\
(-7.20)\end{array}$ & $\begin{array}{l}-0.107 * * * \\
(-10.27)\end{array}$ & $\begin{array}{l}-0.103^{* * *} \\
(-10.28)\end{array}$ & $\begin{array}{l}-0.211^{* * *} \\
(-12.60)\end{array}$ & $\begin{array}{l}-0.171^{* * *} \\
(-11.55)\end{array}$ & $\begin{array}{l}-0.371^{* * *} \\
(-16.28)\end{array}$ \\
\hline U.S. Term Spread * EME & -- & -- & -- & -- & $\begin{array}{l}-0.193^{* * *} \\
(-6.19)\end{array}$ & -- & $\begin{array}{l}-0.356^{* * *} \\
(-8.59)\end{array}$ \\
\hline EME & -- & $\begin{array}{l}-1.784 * * * \\
(-43.93)\end{array}$ & -- & -- & -- & -- & -- \\
\hline \multicolumn{8}{|l|}{ Fixed Effects: } \\
\hline Quarter $\left(D_{t}\right)$ & -- & -- & Yes & -- & -- & -- & -- \\
\hline Bank Country $\left(D_{J}\right)$ & -- & -- & Yes & -- & -- & -- & -- \\
\hline Borrower Country $\left(D_{I}\right)$ & -- & -- & Yes & Yes & Yes & Yes & Yes \\
\hline Bank Country * Quarter $\left(D_{J t}\right)$ & -- & -- & -- & Yes & Yes & Yes & Yes \\
\hline Observations & 43,206 & 43,206 & 43,204 & 43,204 & 43,204 & 40,416 & 40,416 \\
\hline$R$-squared & 0.004 & 0.113 & 0.931 & 0.945 & 0.945 & 0.908 & 0.910 \\
\hline
\end{tabular}

Note: The purpose of this table is to confirm the robustness of the main result in Table III, using data on all forms of bank claims on firms (and not just syndicated credit). This sample also covers a larger set of countries. These data are collected from the BIS Consolidated Banking Statistics. The dependent variable is the logarithm of the claim amount held by a developed market banking sector on a given country in a given quarter. U.S. Interest Rate is the federal funds rate (in percent). U.S. Term Spread is the difference between the 10-year U.S. Treasury yield and the federal funds rate (in percentage points). EME is a dummy variable that equals one if the firm is located in an emerging market country (as defined by BIS), and zero otherwise. DME is a dummy that equals one if the borrower is located in a developed market country, and zero otherwise. The sample covers the period from 2005:Q1 through 2016:Q3, which is the period for which the data are publically available. Robust $t$-statistics are in parentheses. The estimate of the constant is not shown. Standard errors are clustered at the quarter level. ***, **, and * indicate statistical significance at the $1 \%, 5 \%$, and $10 \%$ level, respectively. 
TABLE VII - U.S. MONETARY POLICY AND EME FINANCIAL OPENNESS

\begin{tabular}{|c|c|c|c|c|c|}
\hline \multirow[t]{2}{*}{ Dependent Variable: } & \multicolumn{5}{|c|}{ (Log) Claims on Firms (Nonbank Private Sector) } \\
\hline & $(1)$ & $(2)$ & (3) & (4) & (5) \\
\hline U.S. Interest Rate & $\begin{array}{l}-0.117 * * * \\
(-6.32)\end{array}$ & $\begin{array}{l}-0.080 * * * \\
(-4.11)\end{array}$ & -- & -- & -- \\
\hline Financial Openness Index & $\begin{array}{l}0.286^{* * * *} \\
(2.81)\end{array}$ & $\begin{array}{l}0.375^{* * * *} \\
(3.50)\end{array}$ & $\begin{array}{l}0.416^{* * * *} \\
(4.28)\end{array}$ & $\begin{array}{l}0.463^{* * * *} \\
(4.16)\end{array}$ & $\begin{array}{l}0.215 \\
(1.43)\end{array}$ \\
\hline U.S. Interest Rate * Financial Openness Index & -- & $\begin{array}{l}-0.071 * * * \\
(-9.21)\end{array}$ & $\begin{array}{l}-0.070 \text { *** } \\
(-8.17)\end{array}$ & $\begin{array}{l}-0.081^{* * *} \\
(-5.27)\end{array}$ & $\begin{array}{l}-0.066^{* *} \\
(-2.47)\end{array}$ \\
\hline U.S. Term Spread * Financial Openness Index & -- & -- & -- & $\begin{array}{l}-0.018 \\
(-0.68)\end{array}$ & $\begin{array}{l}-0.034 \\
(-0.87)\end{array}$ \\
\hline Country Rating (1=AAA, $2=$ AA+, etc.) & -- & -- & -- & -- & $\begin{array}{l}-0.082^{* * *} \\
(-3.44)\end{array}$ \\
\hline \multicolumn{6}{|l|}{ Fixed Effects: } \\
\hline Bank Country $\left(D_{J}\right)$ & Yes & Yes & -- & -- & -- \\
\hline Borrower Country $\left(D_{I}\right)$ & Yes & Yes & Yes & Yes & Yes \\
\hline Bank Country * Quarter $\left(D_{J t}\right)$ & -- & -- & Yes & Yes & Yes \\
\hline Observations & 22,049 & 22,049 & 22,008 & 22,008 & 14,750 \\
\hline$R$-squared & 0.500 & 0.500 & 0.525 & 0.525 & 0.516 \\
\hline
\end{tabular}

Note: The dependent variable is the logarithm of the claim amount held by a developed market banking sector on a given emerging market country in a given quarter. U.S. Interest Rate is the federal funds rate (in percent). U.S. Term Spread is the difference between the 10-year U.S. Treasury yield and the federal funds rate (in percentage points). Financial Openness Index measures the capital account openness of the host country. The index ranges from zero to one, with zero indicating the lowest financial openness and one indicating the highest financial openness. Country Rating is the lagged sovereign debt rating of the host country. The sample covers quarterly claims on emerging market countries from 2005:Q1 through 2014:Q4. Robust $t$ statistics are in parentheses. Standard errors are clustered at the quarter level. ***, **, and * indicate statistical significance at the $1 \%, 5 \%$, and $10 \%$ level, respectively. 
TABLE VIII -TOTAL DOLLAR BORROWING AT THE FIRM LEVEL

\begin{tabular}{|c|c|c|c|c|c|c|c|c|}
\hline \multirow[t]{4}{*}{ Dependent Variable: } & \multicolumn{6}{|c|}{ (Log) Borrowing Amount (USD) } & \multicolumn{2}{|c|}{ Interest Rate Spread (bps) } \\
\hline & \multicolumn{4}{|c|}{ Firm-Quarters with Foreign and Domestic Lenders } & \multirow[b]{2}{*}{ All Banks } & \multirow[b]{2}{*}{ All Banks } & \multirow[b]{2}{*}{ All Banks } & \multirow[b]{2}{*}{ All Banks } \\
\hline & $\begin{array}{l}\text { Foreign } \\
\text { Banks }\end{array}$ & $\begin{array}{l}\text { Foreign } \\
\text { Banks }\end{array}$ & $\begin{array}{l}\text { Local } \\
\text { Banks }\end{array}$ & All Banks & & & & \\
\hline & $(1)$ & $(2)$ & $(3)$ & $(4)$ & (5) & $(6)$ & $(7)$ & $(8)$ \\
\hline U.S. Interest Rate & $\begin{array}{l}-0.032 * * * \\
(-2.80)\end{array}$ & -- & -- & -- & -- & -- & -- & -- \\
\hline U.S. Interest Rate * EME & $\begin{array}{l}-0.055^{* * *} \\
(-3.09)\end{array}$ & $\begin{array}{l}-0.075^{* * *} \\
(-4.51)\end{array}$ & $\begin{array}{l}-0.085^{* * *} \\
(-6.61)\end{array}$ & $\begin{array}{l}-0.079 * * * \\
(-5.54)\end{array}$ & $\begin{array}{l}-0.024 * * * \\
(-2.65)\end{array}$ & $\begin{array}{l}-0.036 * * * \\
(-3.10)\end{array}$ & $\begin{array}{l}3.855^{* * *} \\
(2.72)\end{array}$ & $\begin{array}{l}9.402 * * * \\
(4.61)\end{array}$ \\
\hline U.S. Term Spread * EME & -- & -- & -- & -- & -- & $\begin{array}{l}-0.023 \\
(-1.20)\end{array}$ & -- & $\begin{array}{l}10.007^{* * *} \\
(2.82)\end{array}$ \\
\hline \multicolumn{9}{|l|}{ Fixed Effects: } \\
\hline Borrower $\left(D_{i}\right)$ & Yes & Yes & Yes & Yes & Yes & Yes & Yes & Yes \\
\hline Quarter $\left(D_{t}\right)$ & -- & Yes & Yes & Yes & Yes & Yes & Yes & Yes \\
\hline Observations & 24,754 & 24,754 & 24,754 & 24,754 & 40,134 & 40,134 & 30,829 & 30,829 \\
\hline$R$-squared & 0.718 & 0.750 & 0.793 & 0.781 & 0.783 & 0.783 & 0.803 & 0.803 \\
\hline
\end{tabular}

Note: In columns (1) to (7), the dependent variable is the logarithm of the volume of total dollar borrowing (in USD billion) at the firm-quarter level. In columns (8) to (10), the dependent variable is the average all-in-drawn spread to the 3M LIBOR rate (in bps) of all dollar loans the borrower received in a given month. U.S. Interest Rate is the federal funds rate (in percent). U.S. Term Spread is the difference between the 10-year U.S. Treasury yield and the federal funds rate (in percentage points). EME is a dummy variable that equals one if the firm is located in an emerging market country (as defined by BIS), and zero otherwise. The sample period covers 1990:Q1 through 2016:Q3. Columns (1) through (4) contain firm-quarters with lending by both foreign and local banks; the remaining columns are based on all firm-quarters with lending by foreign banks. Robust $t$-statistics are in parentheses. Standard errors are clustered at the quarter level. ***, **, and * indicate statistical significance at the $1 \%, 5 \%$, and $10 \%$ level, respectively. 
TABLE IX -RELIANCE ON GLOBAL BANK CREDIT AND FIRM-LEVEL CREDIT CONDITIONS IN EMES

\begin{tabular}{|c|c|c|c|c|c|c|c|c|}
\hline \multirow[t]{2}{*}{ Dependent Variable: } & \multicolumn{4}{|c|}{ (Log) Borrowing Amount (USD) } & \multicolumn{2}{|c|}{ Interest Rate Spread (bps) } & \multicolumn{2}{|c|}{ Probability of Refinancing } \\
\hline & $(1)$ & $(2)$ & $(3)$ & $(4)$ & $(5)$ & (6) & (7) & (8) \\
\hline U.S. Interest Rate & $\begin{array}{l}-0.175^{* * *} \\
(-8.97)\end{array}$ & $\begin{array}{l}-0.206^{* * *} \\
(-7.04)\end{array}$ & -- & -- & -- & -- & -- & -- \\
\hline Past Foreign Bank Reliance & $\begin{array}{l}0.546 * * * \\
(9.82)\end{array}$ & $\begin{array}{l}0.442^{* * *} \\
(6.11)\end{array}$ & $\begin{array}{l}0.155^{* *} \\
(2.10)\end{array}$ & $\begin{array}{l}0.200 \\
(1.11)\end{array}$ & $\begin{array}{l}-6.111 \\
(-0.62)\end{array}$ & $\begin{array}{l}-75.645^{* * *} \\
(-3.57)\end{array}$ & $\begin{array}{l}0.044 \\
(1.02)\end{array}$ & $\begin{array}{l}0.232 * * * \\
(2.74)\end{array}$ \\
\hline Past Foreign Bank Reliance * U.S. Interest & -- & $\begin{array}{l}0.041^{*} \\
(1.84)\end{array}$ & $\begin{array}{l}-0.035 * \\
(-1.67)\end{array}$ & $\begin{array}{l}-0.042 \\
(-1.19)\end{array}$ & $\begin{array}{l}2.867 \\
(1.18)\end{array}$ & $\begin{array}{l}14.430^{* * * *} \\
(3.78)\end{array}$ & $\begin{array}{l}-0.023^{* *} \\
(-2.37)\end{array}$ & $\begin{array}{l}-0.057^{* * * *} \\
(-3.29)\end{array}$ \\
\hline Past Foreign Bank Reliance * U.S. Term & -- & -- & -- & $\begin{array}{l}-0.017 \\
(-0.27)\end{array}$ & -- & $\begin{array}{l}25.392 * * * \\
(3.42)\end{array}$ & -- & $\begin{array}{l}-0.067 * * \\
(-2.52)\end{array}$ \\
\hline Fixed Effects: & & & & & & & & \\
\hline Borrower $\left(D_{i}\right)$ & -- & -- & Yes & Yes & Yes & Yes & Yes & Yes \\
\hline Quarter $\left(D_{t}\right)$ & -- & -- & Yes & Yes & Yes & Yes & Yes & Yes \\
\hline Observations & 6,246 & 6,246 & 5,227 & 5,227 & 3,469 & 3,469 & 6,943 & 6,943 \\
\hline$R$-squared & 0.120 & 0.120 & 0.732 & 0.732 & 0.789 & 0.790 & 0.354 & 0.355 \\
\hline
\end{tabular}

Note: In columns (1) to (4), the dependent variable is the logarithm of the volume of total dollar borrowing (in USD billion) at the firm-quarter level. In columns (5) and (6), the dependent variable is the average all-in-drawn spread to the 3M LIBOR rate (in basis points) of all dollar loans the EME borrower received in a given month. In columns (7) and (8), the dependent variable is a dummy variable equal to one if an EME firm obtains a new loan in the quarter when an earlier loan matures and zero otherwise. Past Foreign Bank Reliance is the share of global banks from developed countries lending to the firm in the last quarter the firm was borrowing. As before, U.S. Interest Rate is the federal funds rate (in percent). U.S. Term Spread is the difference between the 10-year U.S. Treasury yield and the federal funds rate (in percentage points). The sample period covers 1990:Q1 through 2016:Q3 and contains only EME firms. Robust $t$-statistics are in parentheses. Standard errors are clustered at the quarter level. ***, **, and * indicate statistical significance at the $1 \%, 5 \%$, and $10 \%$ level, respectively. 


\section{APPENDIX}

\section{TABLE A.I - GLOBAL BANKS’ EME LENDING BY REGION AND INDUSTRY}

\begin{tabular}{|c|c|c|c|c|}
\hline & $\begin{array}{l}\text { U.S. Interest Rate * } \\
\text { EME }\end{array}$ & $t$-stat. & Obs. & $R$-squared \\
\hline & \multicolumn{4}{|c|}{ Panel A: Split by Region } \\
\hline EME: Africa & $-0.083^{* * *}$ & $(-5.24)$ & 108,837 & 0.761 \\
\hline EME: Americas & $-0.050^{* * *}$ & $(-3.48)$ & 110,576 & 0.756 \\
\hline EME: Asia & $-0.090 * * *$ & $(-7.49)$ & 122,865 & 0.823 \\
\hline \multirow[t]{2}{*}{ EME: Europe } & $-0.081^{* * *}$ & $(-4.78)$ & 115,527 & 0.796 \\
\hline & \multicolumn{4}{|c|}{ Panel B: Split by Industry } \\
\hline \multicolumn{5}{|l|}{ Tradable } \\
\hline Agriculture, Forestry and Fishing & $-0.135 * * *$ & $(-3.61)$ & 5,797 & 0.944 \\
\hline Mining & $-0.047 * *$ & $(-2.18)$ & 15,117 & 0.755 \\
\hline Manufacturing & $-0.113^{* * *}$ & $(-7.07)$ & 35,651 & 0.824 \\
\hline \multicolumn{5}{|l|}{ Non-Tradable } \\
\hline Construction & -0.058 & $(-0.91)$ & 734 & 0.943 \\
\hline Transp., Communic., Electric, Gas, Sanitary & $-0.051^{* * *}$ & $(-2.78)$ & 28,970 & 0.774 \\
\hline Wholesale Trade & $-0.085^{* *}$ & $(-2.06)$ & 3,154 & 0.862 \\
\hline Retail Trade & -0.038 & $(-0.45)$ & 2,462 & 0.833 \\
\hline Finance, Insurance, Real Estate & $-0.053^{* * *}$ & $(-3.14)$ & 38,621 & 0.874 \\
\hline Services & 0.038 & $(0.86)$ & 10,747 & 0.780 \\
\hline Public Administration & $0.241 *$ & $(1.73)$ & 951 & 0.874 \\
\hline
\end{tabular}

Note: In this table we replicate the baseline result in Table III, column (4) for borrowers from different regions and industries; that is, each coefficient reported in this table corresponds to the same regression estimated based on different subsamples. The common regression equation is given by $\log \left(\right.$ Loan Amount $\left._{j i t}\right)=\beta \cdot U$.S. Interest Rate ${ }_{t} \cdot E M E_{i}+D_{j t}+D_{i}+\epsilon_{j i t}$, where the dependent variable is the logarithm of the loan amount originated by bank $j$ to firm $i$ in quarter $t$. $D_{j t}$ is a bank*quarter fixed effect, and $D_{i}$ is a borrower fixed effect. U.S. Interest Rate is the federal funds rate. EME is a dummy variable that equals one if the firm is located in the corresponding emerging market region (as defined by BIS), and zero otherwise. Offshore centers are excluded from the sample. Industry classification is based on the 1-digit SIC code as reported in DealScan. The sample covers the period from 1990:Q1 through 2016:Q3. Robust $t$-statistics are in parentheses. Standard errors are clustered at the quarter level. $* * *, * *$, and $*$ indicate statistical significance at the $1 \%, 5 \%$, and $10 \%$ level, respectively. 
APPENDIX

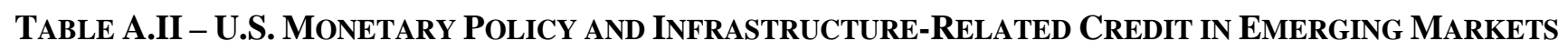

\begin{tabular}{|c|c|c|c|c|c|c|c|c|c|c|}
\hline & \multicolumn{4}{|c|}{ Project Finance Loans } & \multicolumn{6}{|c|}{ Corporate Loans } \\
\hline & \multicolumn{2}{|c|}{ All Projects } & \multicolumn{2}{|c|}{ Infrastructure-Related } & \multicolumn{2}{|c|}{ Infrastructure Sector (WB) } & \multicolumn{2}{|c|}{ Infrastructure Sector (BIS) } & \multicolumn{2}{|c|}{ Maturity $>5 \mathrm{Y}$} \\
\hline & $(1)$ & $(2)$ & (3) & (4) & $(5)$ & $(6)$ & $(7)$ & $(8)$ & (9) & $(10)$ \\
\hline U.S. Interest Rate & $\begin{array}{l}-0.050 * * \\
(-2.60)\end{array}$ & -- & $\begin{array}{l}-0.068 * * \\
(-2.60)\end{array}$ & -- & $\begin{array}{l}-0.003 \\
(-0.24)\end{array}$ & -- & $\begin{array}{l}-0.005 \\
(-0.50)\end{array}$ & -- & $\begin{array}{l}-0.022 * * \\
(-2.20)\end{array}$ & -- \\
\hline U.S. Interest Rate * EME & $\begin{array}{l}-0.084 * * * \\
(-3.28)\end{array}$ & $\begin{array}{l}-0.087 * * * \\
(-3.77)\end{array}$ & $\begin{array}{l}-0.063 * \\
(-1.95)\end{array}$ & $\begin{array}{l}-0.055^{*} \\
(-1.92)\end{array}$ & $\begin{array}{l}-0.044 \\
(-1.56)\end{array}$ & $\begin{array}{l}-0.059 * * \\
(-2.08)\end{array}$ & $\begin{array}{l}-0.066 * * * \\
(-4.03)\end{array}$ & $\begin{array}{l}-0.079 * * * \\
(-4.87)\end{array}$ & $\begin{array}{l}-0.057 * * * \\
(-3.37)\end{array}$ & $\begin{array}{l}-0.070 * * * \\
(-4.63)\end{array}$ \\
\hline EME & $\begin{array}{l}-0.010 \\
(-0.11)\end{array}$ & $\begin{array}{l}0.021 \\
(0.24)\end{array}$ & $\begin{array}{l}-0.151 \\
(-1.24)\end{array}$ & $\begin{array}{l}-0.063 \\
(-0.55)\end{array}$ & -- & -- & -- & -- & -- & -- \\
\hline Fixed Effects: & & & & & & & & & & \\
\hline Quarter $\left(D_{t}\right)$ & -- & Yes & -- & Yes & -- & Yes & -- & Yes & -- & Yes \\
\hline $\operatorname{Bank}\left(D_{j}\right)$ & Yes & Yes & Yes & Yes & Yes & Yes & Yes & Yes & Yes & Yes \\
\hline Borrower $\left(D_{i}\right)$ & -- & -- & -- & -- & Yes & Yes & Yes & Yes & Yes & Yes \\
\hline Observations & 10,494 & 10,493 & 6,458 & 6,458 & 20,340 & 20,340 & 68,220 & 68,220 & 72,850 & 72,850 \\
\hline$R$-squared & 0.177 & 0.292 & 0.206 & 0.359 & 0.705 & 0.730 & 0.693 & 0.716 & 0.768 & 0.787 \\
\hline
\end{tabular}

Note: The dependent variable is the logarithm of the dollar loan amount originated by a given bank to a given firm in a given quarter. U.S. Interest Rate is the federal funds rate (in percent). EME is a dummy variable that equals one if the firm is located in an emerging market country (as defined by BIS), and zero otherwise. The sample covers loans by developed countries banks during the period from 1990:Q1 through 2016:Q3. We use different methods to identify infrastructure-related projects, including the maturity of the loan and sector of the borrower. In columns (3) and (4), we restrict the sample to infrastructure-related projects as classified in World Bank (2016). In columns (5)-(7) we look at corporate loans to borrowers from infrastructure-relevant sectors, based on the classifications by the World Bank (2016) and the BIS (Ehlers 2014). Columns (9) and (10) focus on corporate loans with maturity longer than 5 years, given that infrastructure-related credit is typically of long maturity. Given that the structure of the investment where the assets of the sponsor are ring-fenced and repeated projects by the same sponsor are rare, we do not include borrower fixed effects in Columns (1)-(4). Robust $t$-statistics are in parentheses. Standard errors are clustered at the quarter level. ***, **, and * indicate statistical significance at the $1 \%, 5 \%$, and $10 \%$ level, respectively. 